\title{
POSSIBILITY OF IMPROVING THE GROWTH, YIELD AND SOME CHEMICAL CONSTITUENTS OF TWO LINES OF ROSELLE (Hibiscus sabdariffa, L. ) CULTIVAR SABAHIA 17 PLANTS BY USING CHEMICAL AND ORGANIC FERTILIZATION
}

Ali, A. F.

Hort. Dept. Fac. of Agric., Al Azhar Univ. Assiut.

\section{ABSTRACT}

This study was carried out during the two successive seasons of 2004 and 2005 to determine the role of chemical and organic fertilizers in improving of growth, yield and some chemical constituents of two lines (dark and light) of roselle cultivar "Sabahia 17" plants. NPK fertilizers were applied separately or in combination with organic fertilizers, where nitrogen were used at the rates of $0,33.5$ and $67.0 \mathrm{~kg} \mathrm{~N} /$ feddan ( $\mathrm{N}_{0}, \mathrm{~N}_{1}$ and $\mathrm{N}_{2}$ ), respectively, phosphorus at the rates of $0,15.5$ and $31.0 \mathrm{~kg}$ $\mathrm{P}_{2} \mathrm{O}_{5} /$ feddan $\left(\mathrm{P}_{0}, \mathrm{P}_{1}\right.$ and $\left.\mathrm{P}_{2}\right)$, respectively and potassium at the rates of $0,18.0$ and $36.0 \mathrm{~kg} \mathrm{~K} \mathrm{~K}_{2} \mathrm{O} /$ feddan $\left(\mathrm{K}_{0}, \mathrm{~K}_{1}\right.$ and $\mathrm{K}_{2}$ ), respectively, where these amounts are 0, 50 and $100 \%$ NPK of the recommended doses for the three elements, respectively. Also, organic manures ( chicken manure and sheep manure) were applied at the rates of 0 , 10 and $20 \mathrm{~m}^{3} /$ feddan for each one.

The obtained results revealed that dark line plants gave higher values of branches number, herb dry weight, fruits number, sepals dry yield per plant and / feddan, seed yield per plant and / feddan, anthocyanin \%, N, P and $\mathrm{K} \%$ and uptakes more than light line plants meanwhile, light line plants had more acidity \% than those of dark line plants.

In regard to chemical and organic manure fertilization, generally, it was found that adding organic manure with NPK led to improve the growth, yield and chemical constituents. The results showed that application of chicken manure achieved better results than those of sheep manure. In most cases, the use of $50 \%$ of the recommended doses of NPK fertilization + the high rate of chicken manure gave values near from $100 \% \mathrm{NPK}$ of the recommended doses. Also, the results revealed that the combination of $100 \%$ of the NPK recommended doses + the high rate of chicken manure was the most effective treatment concerning growth, yield and chemical parameters.

Concerning the interaction between the two studied factors, in most cases, it had significant effect and the most effective interaction treatment was obtained when receiving dark line plants $100 \%$ of the NPK recommended doses + the high rate of chicken manure.

It is worthy to mention that applying the combination of $50 \%$ of the NPK recommended doses plus the high rate of chicken manure where, in some cases, applying of $100 \%$ of the NPK recommended doses + the high rate of chicken manure had no significant increase of the sepals yield production than of $50 \%$ of the NPK recommended doses + the high rate of chicken manure. Therefore, it could be recommended to supply dark line plants with the combination of $50 \%$ of the NPK recommended doses + chicken manure at the high rate to obtain high yield, minimizing the chemical fertilizers, improving soil fertility, as well as, minimizing environmental pollution. 
Ali, A. F.

\section{INTRODUCTION}

Roselle ( Hibiscus sabdariffa, L.) plant belongs to Family Malvaceae and cultivated in Egypt for its fleshy calyx from which jelly, jam and a karkadae drink ( Kirby, 1963).The fleshy calyces contain anthocyanin pigments and have a pleasant acid taste. It has antibacterial, fungal and diuretic activities ( Guerin and Reveillere, 1984 and Caceres et al, 1987). Also, the sepals have been used as a flavoring agent and a dye that has an antiseptic action ( Busson et al, 1957). Extract of plant could be used for blood pressure, nerve and heart diseases, as well as, calcified arteries (Griebel, 1939). The fibers of roselle stem may be used as a jute substitute ( Eweida, 1974). In addition, Al-Wandawi, et al (1984) reported that roselle seeds are a source of vegetable oil and proteins. In the meantime, there are many trials aim to increase the productivity of medicinal and aromatic plants including roselle plant with good quality in order to safe these products for both local and exportation markets. Application of organic fertilization is one of the most factors to achieve the safe agriculture, may reduce the use of chemical fertilizer and enhance the purity of agricultural products. Furthermore, organic fertilization plays an important role by the plants supplementation with their nutritional requirements without any undesirable impact on the environment.

Working on dark and light lines of roselle cv. Sabahia 17 plants, Ahmed et al, (1995) and El-Sayed et al, (1995) stated that dark line plants were superior to light line plants in branches number, herb dry weight, number of fruits and anthocyanine \% but acidity \% in light line plants was higher than dark line plants. El-Sayed et al, (1995) showed that dark line plants gave heavier calyces more than light line plants. Meanwhile, light line plants surpassed dark line plants in calyces weight ( Ahmed et al, (1995).

The stimulating effect of NPK fertilization on plant growth, yield and some chemical constituents of roselle plants was studied by many investigators, El-Shafie (1979), Damme and Viaene (1987) and Hassanein (1991) stated that branches number, leaves, stems and calyces yield were increased due to application of NPK fertilization treatments. Ahmed et al, (1995) and Abd El- Malik (1996) found that NPK fertilization increased branches number, herb dry weight, number of fruits and calyces weight. Moreover, Badr (1976), El- Shafie (1979), Hassanein (1991), Ahmed et al, (1995) and Abd-El- Malik (1996) revealed that application of NPK fertilization, led to an increase in anthocyanin pigments. In addition, supplying the plants with NPK fertilization increased the acidity ( Badr, 1976, El- Shafie, 1979, Hassanein, 1991 and Abd El Malik, 1996). Working on some medicinal and aromatic plants, Bhat and Sulikeri (1992) and Ali (1993) found that NPK fertilization treatments increase the seed yield of Coriandrum sativum and Nigella sativa plants, respectively. Moreover, NPK fertilization increased P and K \% and uptake ( Abd El- Malik, 1996). Hassanein (1991) declared that NPK fertilization increased N, P and K contents of roselle. Ali (1993) stated that $\mathrm{N}, \mathrm{P}$ and $\mathrm{K} \%$ and contents of Nigella sativa were increased as a result of NPK fertilization treatments. 
Many investigators emphasized the response of different medicinal and aromatic plants in terms of plant growth, yield and chemical constituents, to organic fertilization treatments. Ahmed et al, (1998) supplied roselle plants with organic manures ( chicken and animal manures ) each at 14, 18, 25 and $27 \mathrm{~m}^{3} /$ fed. and stated that the growth, calyxes quantity and quality were improved as a result of these treatments particularly at the low rates. Hammam (1996) stated that organic fertilization increased N, P and K contents of anise plants. Jacoub (1999) revealed that poultry manure at 20 $\mathrm{m}^{3}$ / fed was the most effective fertilization treatment for sweet basil. He added that branch number and herb dry weight of thyme were increased by application of organic fertilizers. Also, poultry manure and other manures ( cattle and horses) increased $\mathrm{N}, \mathrm{P}$ and $\mathrm{K}$ contents in sweet basil and thyme. Osman (2000) fertilized coriander plants with sheep manure levels (5, 10 and $15 \mathrm{~m}^{3} / \mathrm{fed}$ ) and demonstrated that the high level increased branches number, fruits number and fruits weight and decreased $\mathrm{K} \%$ in herb and carbohydrates \% in herb and fruits while the medium level increased fruit yield, seed index, N and $\mathrm{K}$ in herb and fruits. Ali (2002) declared that application of $20 \mathrm{~m}^{3} /$ fed sheep manure and $200 \mathrm{~kg} /$ fed potassium sulphate increased branches number, fruit yield, N, P and K contents in herb and fruits of fennel. Mallanagouda et al, (1995) stated that supplying coriander plants with NPK at the recommended doses + FYM led to obtain the highest yield, N, P and K uptakes. Sidky et al, ( 1997) mentioned that NPK fertilization application gave higher branches number, fruits number and dry sepals of roselle than organic nutrition ( poultry manure at $6 \mathrm{~m}^{3} /$ fed.). They added that this above manure treatment gave a higher anthocyanin content. Akhtar (1998) reported that the highest yield of Piper betle was obtained from the combination between organic and chemical fertilizers. Mohsen (2002) showed that NPK and organic fertilization ( poultry manure, cattle manure and horse manure ) generally had favorable effect on the herb and found that poultry manure at $24 \mathrm{~m}^{3} /$ fed. was the most effective fertilization treatment and generally, organic fertilizer increased branches number and herb dry weight of sweet basil.

\section{MATERIALS AND METHODS}

This work was carried out at the Experimental Farm, Fac., of Agric., Al-Azhar Univ., Assiut during the two consecutive seasons of 2004 and 2005 to study the influence of chemical and organic fertilizers on growth, yield and some chemical constituents of the two lines of roselle (Hibisscus sabdariffa, L.) cultivar Sabahia 17 plants. Seeds of the two lines ( dark \& light) obtained from Sids Hort. Res. Station, Agric. Res. Center, Beni-Suef Governorate and were sown in the nursery in plots on April $11^{\text {th }}$ of the two seasons. Seedlings were transplanted into the experimental farm 45 days later. Each plot was $3 \times 3 \mathrm{~m}$ and contained 4 rows $60 \mathrm{~cm}$ apart. The distances between the plants were $50 \mathrm{~cm}$. The physical, chemical properties of the Experimental soil and chemical analysis of the organic fertilizers used were shown in Tables (1 and 2 ), respectively. 
Ali, A. F.

Table (1): Physical and chemical properties of the Experimental soil.

\begin{tabular}{|c|c|c|c|c|c|c|c|c|}
\hline \multirow[b]{2}{*}{ Season } & \multirow[b]{2}{*}{ Texture } & \multirow{2}{*}{$\begin{array}{c}\mathrm{CaCO} 3 \\
\%\end{array}$} & \multirow[b]{2}{*}{$\begin{array}{c}\text { pH } \\
(1: 2.5)\end{array}$} & \multirow{2}{*}{$\begin{array}{c}\mathrm{EC}(\mathrm{m} . \\
\text { Mohos } \mathrm{cm})\end{array}$} & \multirow[b]{2}{*}{$\begin{array}{l}\text { O.M } \\
\%\end{array}$} & \multirow{2}{*}{$\begin{array}{c}\text { Total } \\
\mathbf{N} \\
\%\end{array}$} & \multicolumn{2}{|c|}{ Available } \\
\hline & & & & & & & $\begin{array}{c}P \\
\text { (ppm) }\end{array}$ & $\begin{array}{c}\mathrm{K}(\mathrm{mg} / \\
100 \mathrm{~g} \text { soil) }\end{array}$ \\
\hline $1^{\text {st }}$ & Loamy & 2.15 & 7.2 & 2.05 & 0.43 & 0.11 & 18.3 & 2.9 \\
\hline $2^{\text {nd }}$ & Loamy & 2.08 & 7.6 & 2.08 & 0.57 & 0.14 & 19.5 & 2.7 \\
\hline
\end{tabular}

Table (2): Chemical analysis of the organic fertilizers used.

\begin{tabular}{|l|l|c|c|c|c|c|c|c|}
\hline \multicolumn{2}{|c|}{ Content } & O.M \% & N (\%) & P (\%) & K (\%) & $\begin{array}{c}\text { Zn } \\
(\mathbf{p p m})\end{array}$ & $\begin{array}{c}\text { Mn } \\
(\mathbf{p p m})\end{array}$ & $\begin{array}{c}\text { Fe } \\
(\mathbf{p p m})\end{array}$ \\
\hline $\begin{array}{l}\text { Chicken } \\
\text { Manure }\end{array}$ & $1^{\text {st }}$ & 47.90 & 3.65 & 1.12 & 1.88 & 305 & 177 & 5720 \\
\hline $\begin{array}{l}\text { Sheep } \\
\text { Manure }\end{array}$ & $1^{\text {st }}$ & 30.50 & 3.35 & 0.98 & 1.80 & 297 & 187 & 5905 \\
\cline { 2 - 9 } & $2^{\text {nd }}$ & 43.89 & 2.14 & 0.90 & 1.39 & 262 & 63 & 2895 \\
\hline
\end{tabular}

The experimental design was split plot system with 3 replications each of which included 20 plant. The two lines occupied the main plots, while the chemical and organic fertilizer treatments were assigned to the sub- plots.

Organic fertilizers i.e., chicken manure $(\mathrm{Ch})$ and sheep manure $(\mathrm{Sh})$ were applied at the rates of 0,10 and $20 \mathrm{~m}^{3}$ / feddan for each one during soil preparation. In regard to chemical fertilizers ( NPK), nitrogen fertilization ( $\mathrm{N}_{0}$, $\mathrm{N}_{1}$ and $\mathrm{N}_{2}$ ) was applied at the rates of $0,33.5$ and $67.0 \mathrm{~kg} \mathrm{~N} /$ feddan, respectively as ammonium nitrate $(33.5 \% \mathrm{~N})$, phosphorus fertilization $\left(\mathrm{P}_{0}\right.$,

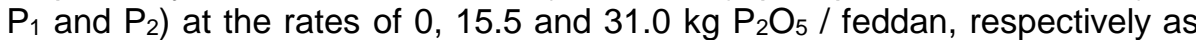
calcium suprphosphate $\left(15.5 \% \mathrm{P}_{2} \mathrm{O}_{5}\right)$ and potassium fertilization $\left(\mathrm{K}_{0}, \mathrm{~K}_{1}\right.$ and $\mathrm{K}_{2}$ ) at the rates of $0,18.0$ and $36.0 \mathrm{~kg} \mathrm{~K} \mathrm{~K}_{2} \mathrm{O} /$ feddan , respectively as potassium sulphate $\left(48 \% \mathrm{~K}_{2} \mathrm{O}\right.$ ), where the NPK of the recommended doses were $67 \mathrm{~kg} \mathrm{~N}, 31 \mathrm{~kg} \mathrm{P}_{2} \mathrm{O}_{5}$ and $36 \mathrm{~kg} \mathrm{~K} \mathrm{~K}_{2} \mathrm{O} /$ feddan. The following combinations treatments between NPK and organic fertilizers : $\mathrm{N}_{0} \mathrm{P}_{0} \mathrm{~K}_{0}$, (unfertilized control), $\mathrm{N}_{1} \mathrm{P}_{1} \mathrm{~K}_{1}$ ( $50 \%$ of the NPK recommended doses), $\mathrm{N}_{2} \mathrm{P}_{2} \mathrm{~K}_{2}$ ( $100 \%$ of the NPK recommended doses), chicken manure at $10 \mathrm{~m}^{3}$ $\left(\mathrm{Ch}_{1}\right)$, chicken manure at $20 \mathrm{~m}^{3}\left(\mathrm{Ch}_{2}\right)$, sheep manure at $10 \mathrm{~m}^{3}\left(\mathrm{Sh}_{1}\right)$, sheep manure at $20 \mathrm{~m}^{3}\left(\mathrm{Sh}_{2}\right), \mathrm{N}_{1} \mathrm{P}_{1} \mathrm{~K}_{1}+$ chicken manure at $10 \mathrm{~m}^{3}\left(\mathrm{Ch}_{1}\right), \mathrm{N}_{1} \mathrm{P}_{1} \mathrm{~K}_{1}+$ chicken manure at $20 \mathrm{~m}^{3}\left(\mathrm{Ch}_{2}\right), \mathrm{N}_{1} \mathrm{P}_{1} \mathrm{~K}_{1}+$ sheep manure at $10 \mathrm{~m}^{3}\left(\mathrm{Sh}_{1}\right)$, $\mathrm{N}_{1} \mathrm{P}_{1} \mathrm{~K}_{1}$ + sheep manure at $20 \mathrm{~m}^{3}\left(\mathrm{Sh}_{2}\right) \mathrm{N}_{2} \mathrm{P}_{2} \mathrm{~K}_{2}$ + chicken manure at $10 \mathrm{~m}^{3}$ $\left(\mathrm{Ch}_{1}\right), \mathrm{N}_{2} \mathrm{P}_{2} \mathrm{~K}_{2}$ + chicken manure at $20 \mathrm{~m}^{3}\left(\mathrm{Ch}_{2}\right), \mathrm{N}_{2} \mathrm{P}_{2} \mathrm{~K}_{2}$ + sheep manure at $10 \mathrm{~m}^{3}\left(\mathrm{Sh}_{1}\right)$ and $\mathrm{N}_{2} \mathrm{P}_{2} \mathrm{~K}_{2}$ + sheep manure at $20 \mathrm{~m}^{3}\left(\mathrm{Sh}_{2}\right)$. The mineral fertilizers were added at two batches at one month interval starting on June $30^{\text {th }}$ of both seasons. The other cultural practices for roselle plant were followed as usual.

At the end of the experiment (on Oct. $17^{\text {th }}$ and Oct. $21^{\text {th }}$ for the first and the second seasons, respectively), the following data were recorded for both seasons: number of branches / plant, herb dry weight $\mathrm{g} /$ plant, number of fruits / plant, sepals dry yield g / plant and seed yield g / plant, while, sepals dry yield $\mathrm{kg} /$ feddan and seed yield $\mathrm{kg} /$ feddan were calculated. Acidity titration was in the air dried sepals as citric acid was determined and calculated by the method of titration against alkali (A.O.A.C, 1970), anthocyanin \% in the air dried sepals was estimated by the method of Fuleki 
and Francis (1968) and developed by Du and Francis (1973). N, P and K percentages in the dry herb were determined according to Page et al, (1982) ,as well as, N, P and $\mathrm{K}$ uptakes were calculated. The obtained results were statistically analyzed according to Little and Hills (1978).

\section{RESULTS AND DISSCUTION}

\section{Number of branches / plant:}

Presented data in Table (3) showed that number of branches was significantly affected as a result of cultivating the two lines plants in both seasons. It is obvious that dark line plants significantly gave more branches number than light line plants by 14.9 and $17.7 \%$ in the first and the second seasons, respectively. Similar observations were obtained by Ahmed et al., (1995) and El-Sayed et al., (1995) on roselle plants.

Concerning mineral and organic fertilization treatments, data in Table (3) revealed that both of them significantly increased the number of branches in comparison with unfertilized control, except plants which were fertilized with $\mathrm{Sh}_{1}$ in the first season. Fertilizing roselle plants with $\mathrm{N}_{2} \mathrm{P}_{2} \mathrm{~K}_{2}+\mathrm{Ch}_{2}$ produced the maximum number of branches which reached 60.5 and $61.4 \%$ over those of check plants in the two growing seasons, respectively. The positive effect of NPK on increasing branches number was studied by Ahmed et al, (1995) and Abd El- Malik (1996) on roselle. Also, the stimulating effect of organic manures on enhancing the number of branches was emphasized on roselle by Ahmed et al, (1998), on thyme by Jacoub (1999), on coriander by Osman (2000) and on sweet basil by Mohsen (2002). However, NPK fertilization application gave better branches number of roselle than organic nutrition (Sidky et al, 1997).

The effect of interaction between the two lines of roselle plants, mineral and organic fertilizers on number of branches was significant in both seasons (Table, 3). Supplying dark line plants $\mathrm{N}_{2} \mathrm{P}_{2} \mathrm{~K}_{2}+\mathrm{Ch}_{2}$ was the most effective combination on increasing branches number / plant compared to other combination treatments in the two seasons.

\section{Herb dry weight $\mathrm{g}$ / plant:}

The main effect of the two lines plants on herb dry weight was statistically significant for the two experimental seasons. It is clear from the obtained data that dark line plants significantly produced the heaviest weight of dry herb during the two experimental seasons, since the increment reached 22.6 and $17.7 \%$ than those of light line plants, respectively, as clearly shown in Table (3). These results are in conformity with those reported on roselle plants by Ahmed et al, (1995) and El-Sayed et al, (1995).

Regarding the effect of mineral and organic fertilizers on herb dry weight, it is obvious that all treatments significantly increased herb dry weight in comparison with control plants except, supplying roselle plants with $\mathrm{Ch}_{1}$, $\mathrm{Sh}_{1}$ and $\mathrm{Sh}_{2}$ in both seasons. The heaviest weights of dry herb were obtained due to treating the plants with $\mathrm{N}_{2} \mathrm{P}_{2} \mathrm{~K}_{2}+\mathrm{Ch}_{2}$ and $\mathrm{N}_{2} \mathrm{P}_{2} \mathrm{~K}_{2}+\mathrm{Ch}_{1}$ which increased herb dry weight by $81.5,98.1,80.2$ and $91.1 \%$ over the control in the first and the second seasons, respectively, as clearly revealed in Table (3). Similar findings for the influence of NPK fertilization on increasing herb 
Ali, A. F.

dry weight were previously obtained by Ahmed et al, (1995) and Abd ElMalik (1996) on roselle.

Table (3): Effect of chemical and organic fertilization treatments on the two lines of roselle cultivar Sabahia 17 plants during 2004 and 2005 seasons.

\begin{tabular}{|c|c|c|c|c|c|c|c|c|c|c|c|c|}
\hline \multirow{4}{*}{\begin{tabular}{|} 
Chemical and \\
organic \\
fertilizer \\
treatments \\
(B)
\end{tabular}} & \multicolumn{3}{|c|}{ First season } & \multicolumn{3}{|c|}{ Second season } & \multicolumn{3}{|c|}{ First season } & \multicolumn{3}{|c|}{ Second season } \\
\hline & \multicolumn{6}{|c|}{ Lines (A) } & \multicolumn{6}{|c|}{ Lines (A) } \\
\hline & ght & Dark & Mea & Light & Dark & I & Light & Dark & Me & Light & Dark & Me \\
\hline & \multicolumn{6}{|c|}{ Number of branches / plant } & \multicolumn{6}{|c|}{ Herb dry weight ( g / plant) } \\
\hline $\mathrm{N}_{0} \mathrm{P}_{0} \mathrm{~K}_{0}$ & 7.1 & 0 & 7.6 & 7.7 & 8.9 & 8.3 & 180.3 & 271.5 & 225 & 215.7 & & 248.3 \\
\hline $\mathrm{N}_{1} \mathrm{P}_{1} \mathrm{~K}_{1}$ & 2 & 9.8 & 9.0 & 8.8 & 10.2 & 9.5 & 310.5 & & & 332.7 & & 368.9 \\
\hline $\mathrm{N}_{2} \mathrm{P}_{2} \mathrm{~K}_{2}$ & 8.7 & 10.7 & 9.7 & 10.3 & 12.0 & 11.2 & 350.3 & 395.0 & 372.7 & 384.1 & 471.0 & 427.6 \\
\hline $\mathrm{Ch}_{1}$ & 0 & 9.0 & 8.5 & 8.4 & 9.7 & 9.1 & 200.1 & & 240.4 & 261.5 & & 290.5 \\
\hline $\mathrm{Ch}_{2}$ & 2 & 9.3 & 8 & 8.5 & 10.4 & 9.5 & 233.7 & 335.1 & 284.4 & 281.5 & .0 & 305.3 \\
\hline $\mathrm{Sh}_{1}$ & 7 & 1 & .9 & 8.2 & 9.5 & 8.9 & 185.0 & & 247.8 & 21 & & 24 \\
\hline $\mathrm{Sh}_{2}$ & 9 & 5 & 8.2 & 8.6 & 10.0 & 9.3 & & & & & & 2 \\
\hline $\mathrm{N}_{1} \mathrm{P}_{1} \mathrm{~K}$ & 8.6 & 9.7 & 9.2 & 9.6 & 11.1 & 10.4 & 337.9 & 387.8 & 362.9 & 340.5 & & 382.9 \\
\hline $\mathrm{N}_{1} \mathrm{P}_{1} \mathrm{~K}_{1}+$ & .5 & 10.3 & 9.9 & 10.2 & 11.8 & 11.0 & 344.0 & & 372.4 & 360.7 & & 40 \\
\hline $\mathrm{N}_{1} \mathrm{P}_{1} \mathrm{~K}_{1}$ & 8.4 & 9.1 & 8.8 & 9.0 & 10.7 & 9.9 & 321.5 & 368.1 & 344.8 & 337.9 & 362.5 & 350.2 \\
\hline $\mathrm{N}_{1} \mathrm{P}_{1} \mathrm{~K}_{1}+\mathrm{Sh}_{2}$ & .9 & 3 & 9.1 & 10.1 & 12.1 & 11.1 & 323.1 & & & & & 377.1 \\
\hline $\mathrm{N}_{2} \mathrm{P}_{2} \mathrm{~K}_{2}+\mathrm{Ch}_{1}$ & 9.6 & 11.5 & 10.6 & 10.3 & 13.7 & 12.0 & 373.0 & 440.9 & 407.0 & 445.7 & .5 & 474.6 \\
\hline $\mathrm{N}_{2} \mathrm{P}_{2} \mathrm{~K}_{2}+\mathrm{Ch}_{2}$ & 10.8 & 13.5 & 12.2 & 12.3 & 14.4 & 13.4 & 382.1 & & 409.9 & 46 & & 491.8 \\
\hline $\mathrm{N}_{2} \mathrm{P}_{2} \mathrm{~K}_{2}+\mathrm{Sh}_{1}$ & 9.3 & 10.7 & 10.0 & 10.5 & 12.3 & 11.4 & 372.3 & 420.0 & 396.2 & 433.1 & & 450.9 \\
\hline $\mathrm{N}_{2} \mathrm{P}_{2} \mathrm{~K}$ & 9.9 & 12.4 & 1 & 11.3 & 13.1 & 12.2 & 369.5 & & 388.7 & 442.3 & & 47 \\
\hline Mean & 8.7 & 10.0 & & 9.6 & 11.3 & & 299.1 & 366.7 & & 341.1 & & \\
\hline \multirow[t]{2}{*}{ L.S.D. for $5 \%$} & 0.5 & B: 0.6 & 0.6 & A:0.8 & 0.5 & & .343 & & & $A: 35$ & 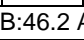 & \\
\hline & \multicolumn{6}{|c|}{ Number of fruits / plant } & \multicolumn{6}{|c|}{ Sepals dry yield g / plant } \\
\hline $\mathrm{N}_{0} \mathrm{~F}$ & 5.9 & 95.5 & 90.7 & 91.3 & 103.7 & 97.5 & 24.6 & & 31.3 & 27.3 & & 35.7 \\
\hline & .5 & 3.8 & & & & & & & & & & \\
\hline $\mathrm{N}_{2} \mathrm{P}_{2} \mathrm{~K}_{2}$ & 15.3 & 142.9 & 129.1 & 127.5 & 151.0 & 139.3 & 38.1 & & 44.2 & 40 & & 50.4 \\
\hline $\mathrm{Ch}_{1}$ & 2.1 & 114.3 & 103.2 & 98.9 & 13 & 116.3 & 25.5 & & 32.9 & 30.0 & & 39.9 \\
\hline $\mathrm{Ch}_{2}$ & 98.7 & 124.9 & 111.8 & 101.9 & 15 & 116.7 & 30.1 & & 37.4 & 34.3 & & 41.0 \\
\hline $\mathrm{Sh}_{1}$ & 4.4 & 107.0 & 100.7 & 96.5 & 1 & 102.1 & 27.0 & & 32.9 & 30.7 & & 37.9 \\
\hline $\mathrm{Sh}_{2}$ & .8 & 6.5 & 103.7 & 103.1 & 11 & 107.8 & 25.5 & & 33.0 & 35.0 & & 41.5 \\
\hline $\mathrm{N}_{1} \mathrm{P}_{1} \mathrm{~K}_{1}$ & 2.4 & 132.1 & 122.3 & 115.2 & 145.2 & 130.2 & 34.9 & & 41.7 & 37.1 & & 45.1 \\
\hline $\mathrm{N}_{1} \mathrm{P}_{1} \mathrm{~K}_{1}+\mathrm{Ch}_{2}$ & 119.9 & 155.9 & 137.9 & 123.9 & 163.9 & 143.9 & 40.2 & & 49.3 & 45.2 & 65.5 & 55.4 \\
\hline $\mathrm{N}_{1} \mathrm{P}_{1} \mathrm{~K}_{1}+\mathrm{Sh}_{1}$ & 0.7 & 120.7 & 110.7 & 105.5 & 156.5 & 131.0 & 39.8 & & 39.9 & 37.7 & & 47.1 \\
\hline $\mathrm{N}_{1} \mathrm{P}_{1} \mathrm{~K}_{1}+\mathrm{Sh}_{2}$ & 05.1 & 140.9 & 123.0 & 113.4 & 163.7 & 138.6 & 41.0 & 49.0 & 45.0 & 38.5 & 66.0 & 52.3 \\
\hline $\mathrm{N}_{2} \mathrm{P}_{2} \mathrm{~K}_{2}+\mathrm{Ch}_{1}$ & 24.3 & 157.5 & 140.9 & 129.7 & 167.5 & 148.6 & 41.1 & & 49.6 & 44.3 & 70.3 & 57.3 \\
\hline $\mathrm{N}_{2} \mathrm{P}_{2} \mathrm{~K}_{2}+\mathrm{Ch}_{2}$ & 127.0 & 160.0 & 143.5 & 131.0 & 171.7 & 151.4 & 44.0 & 63.3 & 53.7 & 46.9 & 72.1 & 59.5 \\
\hline $\mathrm{N}_{2} \mathrm{P}_{2} \mathrm{~K}_{2}+\mathrm{Sh}_{1}$ & 119.2 & 146.9 & 133.1 & 122.7 & 154.2 & 138.5 & 39.0 & & 45.2 & 39.5 & & 47.5 \\
\hline $\mathrm{N}_{2} \mathrm{P}_{2} \mathrm{~K}_{2}+\mathrm{Sh}_{2}$ & 122.8 & 152.0 & 137.4 & 127.1 & 168.0 & 147.6 & 40.8 & 54.7 & 47.8 & 42.0 & 64.0 & 53.0 \\
\hline & 107.1 & 133.1 & & 112.8 & 144.4 & & 34.7 & 48.1 & & 37.5 & 56.9 & \\
\hline L.S.D. for $5 \%$ & $A: 11.1$ & B:10.2 & MD.IV & $\mathrm{A}: 16.7$ & 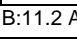 & $\mathrm{AB}: 15.8$ & A:6.9 & B: 4.6 & $A B: 6.5$ & $A: 10.0$ & $B: 4.4$ & HD.U. \\
\hline
\end{tabular}

These results in regard to organic treatments were in accordance with those observed by Ahmed et al, (1998) on roselle, Jacoub (1999) on thyme and Mohsen (2002) on sweet basil.

The interaction between the two factors on herb dry weight had no significant effect in both seasons. 


\section{Number of fruits / plant:}

The influence of the two line plants on number of fruits / plant was significant for both seasons. It is noted that dark line plants significantly recorded the maximum values of fruits number since reached 24.3 and 28.0 $\%$ more than light line plants in the two growing seasons, respectively as clearly indicated in Table (3). These results are in coincidence with those obtained by Ahmed et al, (1995) and El-Sayed et al, (1995) on roselle plants.

Concerning chemical and organic fertilizer treatments, data in Table (3) showed that all of them, except $\mathrm{Sh}_{1}$ in the first season, $\mathrm{Sh}_{1}$ and $\mathrm{Sh}_{2}$ in the second one, significantly increased fruits number compared to unfertilized control. It appeared that the most effective treatments were $\mathrm{N}_{2} \mathrm{P}_{2} \mathrm{~K}_{2}+\mathrm{Ch}_{2}$, $\mathrm{N}_{2} \mathrm{P}_{2} \mathrm{~K}_{2}+\mathrm{Ch}_{1}, \mathrm{~N}_{1} \mathrm{P}_{1} \mathrm{~K}_{1}+\mathrm{Ch}_{2}$ and $\mathrm{N}_{2} \mathrm{P}_{2} \mathrm{~K}_{2}+\mathrm{Sh}_{2}$ which increased the number of fruits by $58.2,55.3,52.0$ and $51.5 \%$ in the first season and $55.3,52.4$, 47.6 and $51.4 \%$ respectively in the second season over untreated ones. The increase in fruits number due to NPK fertilization applied is in agreement with those obtained by Ahmed et al, (1995) and Abd El- Malik (1996) on roselle and Osman (2000) on coriander.

However, the effect of organic fertilizers on improving fruits number was studied by Ahmed et al, (1998) on roselle. NPK fertilization gave more fruits number of roselle than organic nutrition (Sidky et al, 1997).

As far as, the interacting effect on fruits number was significant in the second season only and the best results were observed when fertilizing dark line plants with either $\mathrm{N}_{2} \mathrm{P}_{2} \mathrm{~K}_{2}+\mathrm{Ch}_{2}, \mathrm{~N}_{2} \mathrm{P}_{2} \mathrm{~K}_{2}+\mathrm{Sh}_{2}, \mathrm{~N}_{2} \mathrm{P}_{2} \mathrm{~K}_{2}+\mathrm{Ch}_{1}$ and $\mathrm{N}_{1} \mathrm{P}_{1} \mathrm{~K}_{1}+\mathrm{Ch}_{2}$.

\section{Sepals dry yield $\mathbf{g}$ / plant and $\mathbf{k g}$ / feddan:}

The obtained data in Tables ( 3 and 4 ) revealed that sepals dry yields $\mathrm{g} /$ plant and $\mathrm{kg} /$ feddan were significantly affected by cultivating the two line plants for the two growing seasons. It is clear that dark line plants significantly surpassed light line plants in production of sepals dry yield per plant by 38.6 and $51.7 \%$ where dark line plants produced 427.2 and $505.7 \mathrm{~kg} /$ feddan meanwhile, light line plants gave 308.6 and $333.2 \mathrm{~kg} /$ feddan in the two seasons, respectively. Similar results were found by El-Sayed et al, (1995) on roselle plants.

Data in Tables (3 and 4) obviously showed that all treatments with mineral and organic fertilizers, significantly increased sepals dry yield compared to check treatment, except $\mathrm{Ch}_{1}, \mathrm{Sh}_{1}$ and $\mathrm{Sh}_{2}$ in the first season, $\mathrm{Ch}_{1}$ and $\mathrm{Sh}_{1}$ in the second one. It is noticed that supplying roselle plants with $\mathrm{N}_{2} \mathrm{P}_{2} \mathrm{~K}_{2}+\mathrm{Ch}_{2}, \mathrm{~N}_{2} \mathrm{P}_{2} \mathrm{~K}_{2}+\mathrm{Ch}_{1}$ and $\mathrm{N}_{1} \mathrm{P}_{1} \mathrm{~K}_{1}+\mathrm{Ch}_{2}$ produced the maximum sepals yield per plant which increased it over the control plants by $71.6,66.7,58.5$, $60.5,57.5$ and $55.2 \%$ in both seasons, respectively. These above treatments recorded $477.1,528.8,440.3,509.4,437.7$ and $491.9 \mathrm{~kg} /$ feddan, while unfertilized control gave 278.3 and $317.3 \mathrm{~kg} /$ feddan in the first and the second seasons, respectively. The role of NPK fertilization in increasing sepals yield was emphasized by Ahmed et al, (1995) and Abd El- Malik (1996) on roselle. 
Ali, A. F.

Table (4): Effect of chemical and organic fertilization treatments on the two lines of roselle cultivar Sabahia 17 plants during 2004 and 2005 seasons.

\begin{tabular}{|c|c|c|c|c|c|c|c|c|c|c|c|}
\hline \multirow{4}{*}{\begin{tabular}{|} 
Chemical and \\
organic \\
fertilizer \\
treatments \\
(B)
\end{tabular}} & \multicolumn{2}{|c|}{ First season } & \multicolumn{3}{|c|}{ Second season } & \multicolumn{3}{|c|}{ First season } & \multicolumn{3}{|c|}{ Second season } \\
\hline & \multicolumn{5}{|c|}{ Lines (A) } & \multicolumn{6}{|c|}{ Lines (A) } \\
\hline & \begin{tabular}{|l|l|} 
Light & Dark \\
\end{tabular} & Mean & Ligh & Dark & Mean & $\mathbf{L}$ & Dark & Mean & Light & Dark & Mea \\
\hline & \multicolumn{5}{|c|}{ Sepals dry yield kg / feddan } & \multicolumn{6}{|c|}{ Seed yield g / plant } \\
\hline $\mathrm{N}_{0} \mathrm{P}_{0} \mathrm{~K}_{0}$ & \begin{tabular}{|l|l|}
218.7 & 337.8 \\
\end{tabular} & 78.3 & 242.6 & 392.0 & 317.3 & 2.5 & 8.7 & 35.6 & 35.5 & 50.0 & 42.8 \\
\hline $\mathrm{N}_{1} \mathrm{P}_{1} \mathrm{~K}_{1}$ & \begin{tabular}{|l|l|}
260.1 & 405.9 \\
\end{tabular} & 333.0 & 297.8 & 495.1 & 396.5 & 41.5 & 0.7 & 46.1 & 51.3 & 64.8 & 58.1 \\
\hline $\mathrm{N}_{2} \mathrm{P}_{2} \mathrm{~K}_{2}$ & \begin{tabular}{l|l}
38.7 & 446.8 \\
\end{tabular} & 2.8 & 359.1 & 535.7 & 447.4 & 54.1 & 6.3 & .2 & 60.4 & 76.1 & 68.3 \\
\hline $\mathrm{Ch}_{1}$ & \begin{tabular}{|l|l|}
226.7 & 358.2 \\
\end{tabular} & 2.5 & 266.7 & 441.5 & 354.1 & 35.0 & 6 & 3 & 42.5 & .0 & 2.8 \\
\hline $\mathrm{Ch}_{2}$ & \begin{tabular}{|l|l|}
267.6 & 396.5 \\
\end{tabular} & 2.1 & 304.6 & 423.7 & 364.2 & 38.9 & .5 & 2.7 & 43.0 & 55.9 & 49.5 \\
\hline $\mathrm{Sh}_{1}$ & \begin{tabular}{|l|l|}
240.0 & 344.0 \\
\end{tabular} & 2.0 & 272.9 & 400.0 & & 33.7 & .9 & 3 & 40.7 & 48.5 & 44.6 \\
\hline $\mathrm{Sh}_{2}$ & \begin{tabular}{|l|l|}
226.7 & 359.1 \\
\end{tabular} & 292.9 & 311.1 & 426.7 & 368.9 & 31.8 & 45.5 & 8.7 & 45.4 & 57.3 & 51.4 \\
\hline $\mathrm{N}_{1} \mathrm{P}$ & \begin{tabular}{|l|l|}
310.2 & 431.1 \\
\end{tabular} & & 329.5 & & 400.8 & 42.7 & 5.8 & & 56.2 & 74.5 & 55.4 \\
\hline $\mathrm{N}_{1} \mathrm{P}_{1} \mathrm{~K}_{1}+\mathrm{Ch}_{2}$ & \begin{tabular}{|l|l|}
357.4 & 518.0 \\
\end{tabular} & 437.7 & 401.5 & 582.2 & 491.9 & 50.5 & 72.7 & 61.6 & 61.5 & 80.0 & 70.8 \\
\hline $\mathrm{N}_{1} \mathrm{P}_{1} \mathrm{~K}_{1}+\mathrm{Sh}_{1}$ & \begin{tabular}{|l|l|}
353.5 & 355.6 \\
\end{tabular} & & 334.8 & & & 42.0 & & 8 & 48.1 & 78.3 & 63.2 \\
\hline $\mathrm{N}_{1} \mathrm{P}_{1} \mathrm{~K}_{1}+\mathrm{Sh}_{2}$ & \begin{tabular}{|l|l|}
364.4 & 435.3 \\
\end{tabular} & 399.9 & 342.2 & 586.6 & 464.4 & 45.7 & 70.3 & 58.0 & 54.0 & 82.4 & 68.2 \\
\hline $\mathrm{N}_{2} \mathrm{P}_{2} \mathrm{~K}_{2}+\mathrm{Ch}_{1}$ & \begin{tabular}{|l|l|}
365.0 & 51 \\
\end{tabular} & 44 & 393.8 & & 509.4 & 57.1 & 77.5 & 3 & 67.4 & 85.5 & 76.5 \\
\hline $\mathrm{N}_{2} \mathrm{P}_{2} \mathrm{~K}_{2}+\mathrm{Ch}_{2}$ & \begin{tabular}{|l|l}
391.1 & 563.0 \\
\end{tabular} & 477.1 & 416.6 & 640.9 & 528.8 & 62.4 & 79.0 & 70.7 & 68.1 & 89.1 & 78.6 \\
\hline $\mathrm{N}_{2} \mathrm{P}_{2} \mathrm{~K}_{2}+\mathrm{Sh}_{1}$ & \begin{tabular}{|l|l|}
346.7 & 455.7 \\
\end{tabular} & 401.2 & 351.1 & 3.3 & 422.2 & 55.6 & 72.9 & 64.3 & 59.7 & 74.7 & 67.2 \\
\hline $\mathrm{N}_{2} \mathrm{P}_{2} \mathrm{~K}_{2}+\mathrm{Sh}_{2}$ & \begin{tabular}{|l|l|}
362.7 & 48 \\
\end{tabular} & 4 & & & 471.1 & 1 & & & & 84.9 & 5 \\
\hline Mean & \begin{tabular}{|l|l|}
308.6 & 427.2 \\
\end{tabular} & & 333.2 & 5.7 & & 45.6 & 60.4 & & 53.3 & 71.0 & \\
\hline \multirow[t]{2}{*}{ L.S.D. for $5 \%$} & ancos & & $A: 88$ & & & A & & $A B: 5.5$ & $A: 15.2$ & B:5.2 & 4 \\
\hline & \multicolumn{5}{|c|}{ Seed yield kg / feddan } & \multicolumn{6}{|c|}{ Anthocyanin percentage } \\
\hline $\mathrm{N}_{0} \mathrm{P}_{0} \mathrm{~K}_{0}$ & \begin{tabular}{l|l|}
8.6 & 344.3 \\
\end{tabular} & & 315.4 & & & $\leq$ & 4 & 3 & 0.64 & 2.19 & 1.42 \\
\hline $\mathrm{N}_{1} \mathrm{P}_{1} \mathrm{~K}_{1}$ & \begin{tabular}{|l|l|}
368.9 & 450.4 \\
\end{tabular} & 40 & 455.7 & .0 & 515.9 & 0.75 & 2.89 & 1.82 & 0.64 & 2.81 & 1.73 \\
\hline $\mathrm{N}_{2} \mathrm{P}_{2} \mathrm{~K}_{2}$ & \begin{tabular}{|l|l|}
480.6 & 58 \\
\end{tabular} & & 537.2 & & 606.8 & 0.83 & 2.95 & 89 & 0.79 & 2.96 & 1.88 \\
\hline $\mathrm{Ch}_{1}$ & \begin{tabular}{|l|l|}
311.1 & 369.8 \\
\end{tabular} & & 377.8 & .0 & 468.9 & 0.69 & 2.76 & 1.73 & 0.60 & 2.75 & 1.68 \\
\hline $\mathrm{Ch}_{2}$ & \begin{tabular}{|l|l|}
346.1 & 413.3 \\
\end{tabular} & & 382.2 & & 439.6 & 0.72 & 2.74 & 1.73 & 0.70 & 2.80 & 1.75 \\
\hline $\mathrm{Sh}_{1}$ & \begin{tabular}{|l|l|}
299.3 & 363.9 \\
\end{tabular} & & 361.8 & .8 & & 0.59 & 2.49 & 1.54 & 0.63 & 2.48 & 1.56 \\
\hline $\mathrm{Sh}_{2}$ & \begin{tabular}{|l|l|}
283.0 & 40 \\
\end{tabular} & 34 & 403.6 & & 456.5 & 0.60 & 2.67 & 1.64 & 0.64 & 2.50 & 1.57 \\
\hline $\mathrm{N}_{1} \mathrm{P}_{1} \mathrm{~K}_{1}+\mathrm{Ch}_{1}$ & \begin{tabular}{|l|l|}
379.6 & 585.2 \\
\end{tabular} & 482.4 & 499.5 & 662.2 & 580.9 & 0.75 & 2.81 & 1.78 & 0.62 & 2.76 & 1.69 \\
\hline $\mathrm{N}_{1} \mathrm{P}_{1} \mathrm{~K}_{1}+\mathrm{Ch}_{2}$ & \begin{tabular}{|l|l|}
448.9 & 646.2 \\
\end{tabular} & 547.6 & 546.7 & .1 & 628.9 & 0.77 & 2.99 & 1.88 & 0.71 & 2.92 & 1.82 \\
\hline $\mathrm{N}_{1} \mathrm{P}_{1} \mathrm{~K}_{1}+\mathrm{Sh}_{1}$ & \begin{tabular}{|l|l|}
373.3 & 564.4 \\
\end{tabular} & 468.9 & 427.2 & 696.0 & 561.6 & 0.70 & 2.83 & 1.77 & 0.64 & 2.89 & 1.77 \\
\hline $\mathrm{N}_{1} \mathrm{P}_{1} \mathrm{~K}_{1}+\mathrm{Sh}_{2}$ & \begin{tabular}{|l|l|}
406.5 & 624.9 \\
\end{tabular} & 515.7 & 481.3 & 732.4 & 606.9 & 0.76 & 3.07 & 1.92 & 0.74 & 2.93 & 1.84 \\
\hline $\mathrm{N}_{2} \mathrm{P}_{2} \mathrm{~K}_{2}+\mathrm{Ch}_{1}$ & \begin{tabular}{|l|l|}
507.6 & 688.9 \\
\end{tabular} & 598.3 & 599.4 & & 679.9 & 0.80 & 2.87 & 1.84 & 0.84 & 2.99 & 1.92 \\
\hline $\mathrm{N}_{2} \mathrm{P}_{2} \mathrm{~K}_{2}+\mathrm{Ch}_{2}$ & \begin{tabular}{|l|l|}
554.4 & 702.2 \\
\end{tabular} & 628.3 & 605.1 & .7 & 698.4 & 0.87 & 3.31 & 2.09 & 0.82 & 3.15 & 1.99 \\
\hline $\mathrm{N}_{2} \mathrm{P}_{2} \mathrm{~K}_{2}+\mathrm{Sh}_{1}$ & \begin{tabular}{|l|l|}
494.2 & 648.3 \\
\end{tabular} & 571.3 & 530.9 & 664.3 & 597.6 & 0.82 & 2.97 & 1.90 & 0.78 & 2.85 & 1.82 \\
\hline $\mathrm{N}_{2} \mathrm{P}_{2} \mathrm{~K}_{2}$ & \begin{tabular}{|l|l|}
534.5 & 657.8 \\
\end{tabular} & 596.2 & 586.7 & 754.7 & 670.7 & 0.84 & 3.11 & 1.98 & 0.85 & 3.03 & 1.94 \\
\hline Mean & \begin{tabular}{|l|l|}
405.1 & 536.9 \\
\end{tabular} & & 474.0 & 631.1 & & 0.74 & 2.85 & & 0.71 & 2.80 & \\
\hline
\end{tabular}

The positive effect of organic fertilizers in enhancing sepals yield was found by Ahmed et al, (1998) on roselle. Using of NPK fertilization led to obtain high production of dry sepals in roselle more than those of organic nutrition (Sidky et al, 1997). A combination of organic and chemical fertilizers gave the highest yield of Piper betle (Akhtar, 1998).

In regard to the interaction between the two lines, chemical and organic fertilizer treatments, data in Tables ( 3 and 4 ) showed that it had a significant effect on sepals dry yield per plant and / feddan in the two experimental seasons. It is noted that the most effective combinations were detected from treating dark line plants with $\mathrm{N}_{2} \mathrm{P}_{2} \mathrm{~K}_{2}+\mathrm{Ch}_{2}, \mathrm{~N}_{1} \mathrm{P}_{1} \mathrm{~K}_{1}+\mathrm{Ch}_{2}$ and 
$\mathrm{N}_{2} \mathrm{P}_{2} \mathrm{~K}_{2}+\mathrm{Ch}_{1}$ which produced 563.0, 640.9, 518.0, 582.2, 515.5 and $624.9 \mathrm{~kg}$ / feddan for the two seasons, respectively.

Seeds yield $\mathbf{g}$ / plant and $\mathbf{k g}$ / feddan:

Recorded results in Table (4) indicated that the effect of the tested roselle lines on seeds yield / plant and / feddan was statistically significant in both seasons. It appeared that dark line plants produced the highest yield per plant which reached 32.5 and $33.2 \%$ more than light line plants in the two experimental seasons, respectively. Plants of dark line recorded 536.9 and $629.3 \mathrm{~kg} /$ feddan compared to the production of light line plants ( 405.1 and $474.0) \mathrm{kg} /$ feddan in the two seasons, respectively.

With respect to the influence of chemical and organic fertilization treatments, it is obvious that all of them, except the plants received $\mathrm{Ch}_{1}, \mathrm{Sh}_{1}$ and $\mathrm{Sh}_{2}$ in the first season and $\mathrm{Sh}_{1}$ in the second one, significantly increased seed yield / plant and / feddan in comparison with unfertilized plants. The best results were obtained when supplying the plants with $\mathrm{N}_{2} \mathrm{P}_{2} \mathrm{~K}_{2}+\mathrm{Ch}_{2}$, $\mathrm{N}_{2} \mathrm{P}_{2} \mathrm{~K}_{2}+\mathrm{Ch}_{1}$ and $\mathrm{N}_{2} \mathrm{P}_{2} \mathrm{~K}_{2}+\mathrm{Sh}_{2}$ which increased seed yield per plant over the control by $98.6,83.6,89.0,78.7,88.5$ and $76.4 \%$ in the two seasons, respectively and these treatments produced 628.3, 698.4, 598.3, 679.9, 596.2 and $670.7 \mathrm{~kg} /$ feddan comparing to untreated ones (316.5 and 379.9 $\mathrm{kg} /$ feddan in the two growing seasons, respectively), as shown in Table (4). The favorable effect of NPK fertilization on the seed yield is in agreement with those obtained by Bhat and Sulikeri (1992) on Coriandrum sativum and Ali (1993) on Nigella sativa.

The stimulating effect of organic manure on seed yield was emphasized by Ahmed et al, (1998) on roselle. Application of NPK fertilization at the recommended doses + FYM produced the highest yield of coriander ( Mallanagouda et al, 1995).

The interaction between the two studied factors on seed yield / plant and per feddan was statistically significant in both seasons. Fertilizing dark line plants with $\mathrm{N}_{2} \mathrm{P}_{2} \mathrm{~K}_{2}+$ either $\mathrm{Ch}_{2}$ or $\mathrm{Ch}_{1}$ or $\mathrm{Sh}_{2}$ produced the maximum seed yield per plant and / feddan in the two experimental seasons which recorded (702.2, 791.7, 688.9, 760.3, 657.8 and 754.7) $\mathrm{kg} /$ feddan in the first and the second seasons, respectively, as clearly revealed in Table (4).

\section{Anthocyanin percentage:}

Anthocyanin percentage was significantly affected by the two line plants. It is clear from the obtained data that sepals of dark line plants contained higher anthocyanin percentage which reached 285.1 and $294.4 \%$ over in sepals of light line plants in the two seasons, respectively as clearly indicated in Table (4). These results are in accordance with those obtained by Ahmed et al, (1995) and El-Sayed et al, (1995) on roselle plants.

In regard to the use of mineral and organic fertilizers, all treatments, except $S h_{1}$ in the first season, $S h_{1}$ and $S_{2}$ in the second one, significantly increased anthocyanin percentage compared to untreated plants. Supplying roselle plants with $\mathrm{N}_{2} \mathrm{P}_{2} \mathrm{~K}_{2}+\mathrm{Ch}_{2}$ and $\mathrm{N}_{2} \mathrm{P}_{2} \mathrm{~K}_{2}+\mathrm{Sh}_{2}$ gave the maximum value of anthocyanin percentage which reached $46.2,40.1,38.5$ and $36.6 \%$ more than those of unfertilized ones in both seasons, respectively (Table, 4). The increase in anthocyanin percentage as a result of NPK fertilization treatments 
Ali, A. F.

has been observed by many researchers such as, Hassanein (1991), Ahmed et al, (1995) and Abd-El- Malik (1996) on roselle plants.

Table( 5 )Effect of chemical and organic fertilization treatments on the two lines of roselle cultivar Sabahia 17 plants during 2004 and 2005 seasons.

\begin{tabular}{|c|c|c|c|c|c|c|c|c|c|c|c|c|}
\hline \multirow{4}{*}{$\begin{array}{c}\text { Chemical } \\
\text { and } \\
\text { organic } \\
\text { fertilizer } \\
\text { treatments } \\
\text { (B) }\end{array}$} & \multicolumn{3}{|c|}{ First season } & \multirow{2}{*}{\multicolumn{3}{|c|}{ Second season }} & \multicolumn{6}{|c|}{\begin{tabular}{l|l|} 
First season & Second season
\end{tabular}} \\
\hline & \multicolumn{3}{|c|}{ Lines (A) } & & & & \multirow{2}{*}{\multicolumn{6}{|c|}{\begin{tabular}{|l|}
\multicolumn{2}{|c|}{ Lines (A) } \\
Light|Dark $\mid$ Mean Light|Dark|Mean
\end{tabular}}} \\
\hline & Light & Dark & Mean & Light & Da & Mean & & & & & & \\
\hline & \multicolumn{6}{|c|}{ Acidity percentage } & \multicolumn{6}{|c|}{ Nitrogen percentage } \\
\hline $\mathrm{N}_{0} \mathrm{P}_{0} \mathrm{~K}_{0}$ & .85 & 17 & 9.51 & 10.50 & 8.35 & 9.43 & 21 & 27 & 1.24 & 1.29 & 1.41 & 101.35 \\
\hline & 5 & & 95 & TL. & & 86 & 31 & & 39 & 1.40 & 1.63 & 52 \\
\hline & .85 & 07 & .46 & 12.68 & 9.82 & 25 & 55 & 78 & 67 & 1.56 & 1.86 & 1.71 \\
\hline & 90 & 97 & 44 & 151 & 87 & & 23 & 1.20 & 22 & 1.28 & \begin{tabular}{|l|l|}
1.44 \\
\end{tabular} & 71.36 \\
\hline $\mathrm{n}_{2}$ & .97 & & & 11.40 & 9.17 & & 25 & 1.39 & 32 & 1.32 & 1.54 & .43 \\
\hline$\eta_{1}$ & .55 & & & 11.53 & 8.50 & .02 & 27 & 1.18 & 23 & 1.30 & 1.48 & \begin{tabular}{|l|l|}
3 & 1.39 \\
\end{tabular} \\
\hline $\mathrm{h}_{2}$ & .80 & & .27 & 11.60 & 8.90 & 0.25 & 20 & 1.50 & 35 & 1.35 & 1.60 & 1.48 \\
\hline $\begin{array}{l}\mathrm{P}_{1} \mathrm{~K}_{1} \\
\mathrm{~h}_{1}\end{array}$ & 1 & & 1 & 12.16 & 072 & 4 & 36 & 1.56 & 46 & 1.38 & 1.76 & 1.57 \\
\hline $1+\mathrm{Ch}_{2}$ & & & & & 97 & & 47 & 55 & 56 & 1.58 & 1.81 & 1.70 \\
\hline${ }_{1} \mathrm{~K}_{1}+\mathrm{Sh}_{1}$ & 05 & & & 12.13 & 9.63 & & 41 & 1.53 & 47 & 1.36 & 1.57 & 1.47 \\
\hline $\mathrm{P}_{1} \mathrm{~K}_{1}+\mathrm{Sh}_{2}$ & 35 & & & 12.27 & 9.77 & & .45 & 1.61 & 53 & 1.51 & 1.74 & 1.63 \\
\hline${ }_{2} \mathrm{P}_{2} \mathrm{~K}_{2}+\mathrm{Ch}_{1}$ & 05 & 5 & & 12.50 & 10.08 & 1.29 & 52 & 1.70 & 61 & 1.79 & 2.01 & 1.90 \\
\hline & & & & & & & 5 & & & 1.97 & 2.13 & .05 \\
\hline & & & & & & & 68 & & & 1.72 & 1.99 & 1.86 \\
\hline & & & & & & & 71 & & & 1.82 & 2.15 & 1.99 \\
\hline Mear & 12.35 & 9.64 & & 12.09 & 9.53 & & 1.42 & 1.54 & & 1.51 & 1.74 & \\
\hline \multirow[t]{2}{*}{ L.S.D. for $5 \%$} & \multirow{2}{*}{\multicolumn{6}{|c|}{\begin{tabular}{c|c} 
A:2.41 B:0.51 AB:N.S. & A:1.70 B:0.81 \\
Phosphorus percentage
\end{tabular}}} & $A: 0.11 \mathrm{E}$ & & n & & & $\mathrm{B}: 0$. \\
\hline & & & & & & & \multicolumn{6}{|c|}{ potassium percentage } \\
\hline & 100 & 0.189 & 175 & 0.198 & 0.219 & $y$ & 0.66 & 0.77 & 0.72 & 0.79 & 0.85 & 0.82 \\
\hline & & & & & & & 0.85 & & 94 & 0.91 & 1.05 & 0.98 \\
\hline $\mathrm{N}_{2} \mathrm{P}_{2} \mathrm{~K}_{2}$ & 245 & 0 & & 0.268 & 0 & & 0.97 & 1.11 & 1.04 & 0.96 & 1.16 & 1.06 \\
\hline$h_{1}$ & 75 & & & 5 & 0 & 3 & 0.79 & 0.75 & 0.77 & 0.84 & 0.89 & 0.87 \\
\hline $\mathrm{h}_{2}$ & 88 & & & 0.210 & 52 & 0.231 & 0.82 & 0.80 & 81 & 0.95 & 0.88 & 0.92 \\
\hline$h_{1}$ & & & & 12 & 14 & & 0.73 & & 74 & 0.85 & 0.92 & 0.89 \\
\hline & & & & & & & 70 & & 76 & 0.86 & 0.94 & 0.90 \\
\hline $\begin{array}{ll}\mathrm{d}_{1} \mathrm{P}_{1} \mathrm{~K}_{1} \\
\mathrm{Ch}_{1}\end{array}$ & 0.225 & 0 . & 0.2 & 0.250 & 0.235 & 0.243 & 0.87 & 0.92 & .90 & 0.96 & 0.93 & .95 \\
\hline $\mathrm{N}_{1} \mathrm{P}_{1} \mathrm{~K}_{1}+\mathrm{Ch}_{2}$ & & & & & & & 98 & & 02 & 1.00 & 1.13 & 1.07 \\
\hline $\mathrm{N}_{1} \mathrm{P}_{1} \mathrm{~K}_{1}+\mathrm{Sh}_{1}$ & 210 & 0 & & 0.263 & 0.257 & 260 & 0.86 & 0.95 & 91 & 1.04 & 1.09 & 1.07 \\
\hline $\mathrm{N}_{1} \mathrm{P}_{1} \mathrm{~K}_{1}+\mathrm{Sh}_{2}$ & 0.235 & & & 0.273 & & & 0.90 & & 94 & $\mid 1.03$ & 1.15 & 1.09 \\
\hline $2+\mathrm{Ch}_{1}$ & \begin{tabular}{|l|}
0.240 \\
\end{tabular} & & & 0.275 & 0 & & 1.03 & \begin{tabular}{|l|}
0.97 \\
\end{tabular} & 00 & 0.98 & 1.19 & 1.0 \\
\hline$+\mathrm{Ch}_{2}$ & 267 & & & 321 & & & 1.13 & 1.18 & 16 & 1.24 & 1.22 & 1.23 \\
\hline & 27 & & & 0.251 & & 1 & 1.01 & \begin{tabular}{|l|}
1.15 \\
\end{tabular} & \begin{tabular}{|l|}
1.08 \\
\end{tabular} & \begin{tabular}{|l|}
1.03 \\
\end{tabular} & 1.10 & 1.07 \\
\hline $\mathrm{K}_{2}+\mathrm{Sh}_{2}$ & 0.255 & 0.332 & 0.294 & 0.280 & 0.336 & 0.308 & 1.07 & \begin{tabular}{|l|}
1.12 \\
\end{tabular} & \begin{tabular}{|l|}
1.10 \\
\end{tabular} & \begin{tabular}{|l|}
1.17 \\
\end{tabular} & 1.27 & 1.22 \\
\hline Mean & \begin{tabular}{|l|l|}
0.213 \\
\end{tabular} & 0.263 & & 0.245 & 0.277 & & \begin{tabular}{|l|}
0.89 \\
\end{tabular} & 0.96 & & 0.97 & 1.05 & \\
\hline 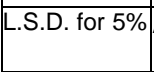 & $A: 0.04$ & $\mathrm{~B}: 0.02$ & DU. & A:0.029 & 3:0.024 & B:0.034 & $\mathrm{A}: 0$. & $05 \mathrm{~B}: \mathrm{C}$ & & & $07 \mathrm{~B}:$ & 0.06 \\
\hline
\end{tabular}

The efficiency of organic fertilizers on anthocyanin percentage has previously been obtained by Ahmed et al, (1998) on roselle.

As for the interaction, data in Table (4) revealed that it had significant effect on anthocyanin percentage in the two experimental seasons. The most 
effective combinations were detected when treating dark line plants with $\mathrm{N}_{2} \mathrm{P}_{2} \mathrm{~K}_{2}+\mathrm{Ch}_{2}, \mathrm{~N}_{2} \mathrm{P}_{2} \mathrm{~K}_{2}+\mathrm{Sh}_{2}$, and $\mathrm{N}_{1} \mathrm{P}_{1} \mathrm{~K}_{1}+\mathrm{Sh}_{2}$ in both seasons.

Acidity percentage :

Data listed in Table (5) showed that the influence of two line plants on acidity percentage in the sepals was statistically significant in the two seasons. It appeared that light line plants gave more acidity percentage than those of dark line plants by 28.2 and $26.9 \%$ in the two experimental seasons, respectively. These results are in harmony with those obtained on roselle plants by Ahmed et al, (1995) and El-Sayed et al, (1995).

Concerning the effect of chemical and organic fertilization treatments, all of them significantly increased acidity percentage in both seasons, except $\mathrm{Ch}_{1}$ and $\mathrm{Sh}_{1}$ in the second season. Receiving roselle plants $\mathrm{N}_{2} \mathrm{P}_{2} \mathrm{~K}_{2}+\mathrm{Ch}_{2}$, $\mathrm{N}_{2} \mathrm{P}_{2} \mathrm{~K}_{2}+\mathrm{Sh}_{2}, \mathrm{~N}_{2} \mathrm{P}_{2} \mathrm{~K}_{2}+\mathrm{Sh}_{1}$ and $\mathrm{N}_{2} \mathrm{P}_{2} \mathrm{~K}_{2}+\mathrm{Ch}_{1}$ gave the maximum values of acidity percentage which increased it by 26.3, 24.1, 25.6, 24.1, 23.7, 18.8, 23.6 and $19.7 \%$ over the control treatment in the first and the second seasons, respectively, as clearly shown in Table (5). The role of NPK fertilization in enhancing acidity percentage was studied on roselle by Badr (1976), El- Shafie (1979), Hassanein (1991) and Abd El Malik (1996).

The combined effect of the two studied factors on acidity percentage was not significant in the two seasons.

Nitrogen, phosphorus and potassium percentages:

Nitrogen, phosphorus and potassium percentages were significantly affected by the two lines of cultivar Sabahia 17 plants in both seasons. It was found that dark line plants gave higher values of nitrogen, phosphorus and potassium percentages more than those of light line plants which reached 8.5 and $15.2 \%$ for nitrogen, 23.5 and $13.1 \%$ for phosphorus and 7.9 and $8.2 \%$ for potassium in the first and the second seasons, respectively (Table 5).

Regarding the effect of chemical and organic fertilization, the results showed that all treatments, except $\mathrm{Ch}_{1}$ and $\mathrm{Sh}_{1}$ in both seasons, significantly increased nitrogen percentage in comparison with untreated plants. The maximum values of nitrogen percentage were obtained in plants fertilized with $\mathrm{N}_{2} \mathrm{P}_{2} \mathrm{~K}_{2}+\mathrm{Ch}_{2}, \mathrm{~N}_{2} \mathrm{P}_{2} \mathrm{~K}_{2}+\mathrm{Sh}_{1}$ and $\mathrm{N}_{2} \mathrm{P}_{2} \mathrm{~K}_{2}+\mathrm{Sh}_{2}$ which increased it by $45.2,51.9,39.5,37.8,36.3$ and $47.4 \%$ over unfertilized ones in the two growing seasons, respectively.

As for phosphorus percentage, it is obvious that chemical and organic fertilization treatments significantly increased phosphorus percentage compared to untreated control, except treating plants with $\mathrm{Sh}_{1}$ and $\mathrm{Sh}_{2}$ in the first season and with $\mathrm{Ch}_{1}, \mathrm{Ch}_{2}, \mathrm{Sh}_{1}$ and $\mathrm{Sh}_{2}$ in the second one. The highest percentages of phosphorus were observed when supplying roselle plants with $\mathrm{N}_{2} \mathrm{P}_{2} \mathrm{~K}_{2}+\mathrm{Ch}_{2}, \mathrm{~N}_{2} \mathrm{P}_{2} \mathrm{~K}_{2}+\mathrm{Sh}_{2}$ and $\mathrm{N}_{2} \mathrm{P}_{2} \mathrm{~K}_{2}+\mathrm{Ch}_{1}$ as increased it by 68.6, 61.2, $68.0,47.4,64.6$ and $44.0 \%$ over untreated plants for the two consecutive seasons, respectively. Concerning potassium percentage, all chemical and organic fertilization treatments, except $\mathrm{Ch}_{1}, \mathrm{Sh}_{1}$ and $\mathrm{Sh}_{2}$ in the first season and $\mathrm{Ch}_{1}$ in the second one significantly increased potassium percentage in comparison with unfertilized control. Receiving roselle plants $\mathrm{N}_{2} \mathrm{P}_{2} \mathrm{~K}_{2}+\mathrm{Ch}_{2}$ and $\mathrm{N}_{2} \mathrm{P}_{2} \mathrm{~K}_{2}+\mathrm{Sh}_{2}$ recorded the highest values and reached 61.1, 50.0, 52.8 and $48.8 \%$ more than control in the two seasons, respectively, as clearly revealed in Table (5). These results in regard to $P$ and $K \%$ are confirmed 
Ali, A. F.

with those observed by Abd El- Malik (1996) on roselle. The positive effect of NPK fertilization treatments on nitrogen, phosphorus and potassium percentages was noticed by Ali (1993) on Nigella sativa.

The combined effect was significant on nitrogen, phosphorus and potassium percentages for the two seasons. It is obvious that fertilizing dark line plants with $\mathrm{N}_{2} \mathrm{P}_{2} \mathrm{~K}_{2}+\mathrm{Ch}_{2}$ and $\mathrm{N}_{2} \mathrm{P}_{2} \mathrm{~K}_{2}+\mathrm{Sh}_{1}$ or supplying light line plants with $\mathrm{N}_{2} \mathrm{P}_{2} \mathrm{~K}_{2}+\mathrm{Ch}_{2}$ were the most effective combinations in the first season. In the second season, the most effective combinations were detected when dark line plants received $\mathrm{N}_{2} \mathrm{P}_{2} \mathrm{~K}_{2}+\mathrm{Sh}_{2}$ followed by $\mathrm{N}_{2} \mathrm{P}_{2} \mathrm{~K}_{2}+\mathrm{Ch}_{2}$. Concerning phosphorus percentage, it cleared that fertilizing dark line plants with $\mathrm{N}_{2} \mathrm{P}_{2} \mathrm{~K}_{2}$ $+\mathrm{Ch}_{1}, \mathrm{~N}_{2} \mathrm{P}_{2} \mathrm{~K}_{2}+\mathrm{Sh}_{2}, \mathrm{~N}_{2} \mathrm{P}_{2} \mathrm{~K}_{2}+\mathrm{Ch}_{2}$ and $\mathrm{N}_{2} \mathrm{P}_{2} \mathrm{~K}_{2}+\mathrm{Sh}_{1}$ gave the highest values of phosphorus percentages in the two seasons. Regarding potassium percentage, it is noticed that receiving dark line plants $\mathrm{N}_{2} \mathrm{P}_{2} \mathrm{~K}_{2}+\mathrm{Ch}_{2}, \mathrm{~N}_{2} \mathrm{P}_{2} \mathrm{~K}_{2}$ $+\mathrm{Sh}_{1}$ and $\mathrm{N}_{2} \mathrm{P}_{2} \mathrm{~K}_{2}+\mathrm{Sh}_{2}$ or fertilizing light line plants with $\mathrm{N}_{2} \mathrm{P}_{2} \mathrm{~K}_{2}+\mathrm{Ch}_{2}$ recorded the maximum value of potassium percentages in the first season. However, in the second season, the most effective combinations were obtained when received dark line plants $\mathrm{N}_{2} \mathrm{P}_{2} \mathrm{~K}_{2}+\mathrm{Sh}_{2}$ and $\mathrm{N}_{2} \mathrm{P}_{2} \mathrm{~K}_{2}+\mathrm{Ch}_{2}$ or treating light line plants with $\mathrm{N}_{2} \mathrm{P}_{2} \mathrm{~K}_{2}+\mathrm{Ch}_{2}$ and $\mathrm{N}_{2} \mathrm{P}_{2} \mathrm{~K}_{2}+\mathrm{Sh}_{2}$.

\section{Nitrogen, phosphorus and potassium uptake ( $g$ / plant):}

It is evident from the data in Tables (6 and 7 ) that $\mathrm{N}, \mathrm{P}$ and $\mathrm{K}$ uptakes were positively affected as a result of cultivating the two lines of roselle in the two growing seasons. The dark line plants absorbed $\mathrm{N}, \mathrm{P}$ and $\mathrm{K}$ elements (5.75, 0.989 and $3.58 \mathrm{~g} /$ plant) more than the light line plants $(4.38,0.662$ and $2.76 \mathrm{~g} /$ plant), respectively in the first season. However, in the second season, the dark line plants absorbed $\mathrm{N}, \mathrm{P}$ and $\mathrm{K}$ elements $(7.17,1.144$ and $4.31 \mathrm{~g} /$ plant), while the light line plants absorbed $(5.31,0.863$ and $3.40 \mathrm{~g} /$ plant), respectively.

With respect to chemical and organic fertilization treatments, data indicated that all of them, except $\mathrm{Ch}_{1}, \mathrm{Sh}_{1}$ and $\mathrm{Sh}_{2}$ in the two seasons, significantly increased $\mathrm{P}$ and $\mathrm{K}$ uptakes compared to untreated control. Similar results were obtained concerning $\mathrm{N}$ uptake, where $\mathrm{Sh}_{2}$ applied had significant effect in the second season. In addition that supplying roselle plants with $\mathrm{N}_{2} \mathrm{P}_{2} \mathrm{~K}_{2}+$ $\mathrm{Ch}_{2}$ followed by $\mathrm{N}_{2} \mathrm{P}_{2} \mathrm{~K}_{2}+\mathrm{Sh}_{1}$ gave higher $\mathrm{N}$ uptake (7.39 and $6.85 \mathrm{~g} /$ plant), respectively in comparison with control $(2.81 \mathrm{~g} /$ plant) for the first season and $\mathrm{N}_{2} \mathrm{P}_{2} \mathrm{~K}_{2}+\mathrm{Ch}_{1}$ followed by $\mathrm{N}_{2} \mathrm{P}_{2} \mathrm{~K}_{2}+\mathrm{Sh}_{2}(10.11$ and $9.39 \mathrm{~g} /$ plant), while the chick treatment absorbed (3.38 g / plant) in the second season. As for $P$ uptake, the obtained data revealed that receiving roselle plants $\mathrm{N}_{2} \mathrm{P}_{2} \mathrm{~K}_{2}+$ $\mathrm{Ch}_{2}, \mathrm{~N}_{2} \mathrm{P}_{2} \mathrm{~K}_{2}+\mathrm{Ch}_{1}, \mathrm{~N}_{2} \mathrm{P}_{2} \mathrm{~K}_{2}+\mathrm{Sh}_{2}$ and $\mathrm{N}_{2} \mathrm{P}_{2} \mathrm{~K}_{2}+\mathrm{Sh}_{1}$ recorded the highest values of $P(1.206,1.183,1.146$ and $1.100 \mathrm{~g} /$ plant), respectively compared to unfertilized ones $(0.401 \mathrm{~g} / \mathrm{plant})$ in the first season. However, the treatment with $\mathrm{N}_{2} \mathrm{P}_{2} \mathrm{~K}_{2}+\mathrm{Ch}_{2}$ gave the highest $\mathrm{P}$ uptake (1.660 g / plant), while the control recorded $(0.523 \mathrm{~g} /$ plant) for the second season. 
Table (6): Effect of chemical and organic fertilization treatments on the two lines of roselle cultivar Sabahia 17 plants during 2004 and 2005 seasons.

\begin{tabular}{|c|c|c|c|c|c|c|c|c|c|c|}
\hline \multirow{4}{*}{\begin{tabular}{|c|} 
Chemical \\
and organic \\
fertilizer \\
treatments \\
(B)
\end{tabular}} & \multicolumn{3}{|c|}{ First season } & \multicolumn{3}{|c|}{ Second season } & \multicolumn{3}{|c|}{ First season } & \multirow{2}{*}{ Second season } \\
\hline & \multicolumn{6}{|c|}{ Lines (A) } & \multicolumn{3}{|c|}{ Lines (A) } & \\
\hline & Light & Dark & Me & Light & Dark & Mean & Light & Dark & ean & \begin{tabular}{|l|l|} 
Light & Dark \\
\end{tabular} \\
\hline & \multicolumn{6}{|c|}{$\mathrm{N}$ uptake $\mathrm{g}$ / plant } & \multicolumn{4}{|c|}{ P uptake $\mathrm{g}$ / plant } \\
\hline $\mathrm{N}_{0} \mathrm{P}_{0} \mathrm{~K}_{0}$ & 17 & 3.44 & 31 & 2.79 & 3.97 & 3.38 & 291 & 511 & 401 & \begin{tabular}{|l|l|}
.616 & 0.523
\end{tabular} \\
\hline & 4.09 & & & 4.65 & & 5.63 & 60 & & & 0 \\
\hline & 47 & 7.02 & & 6.03 & 8.74 & 7.39 & 0.856 & 4 & & 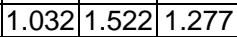 \\
\hline$h_{1}$ & 45 & 3.37 & & 3.32 & 4.62 & 3.97 & & & & .653 \\
\hline $\mathrm{Ch}_{2}$ & 92 & 4.66 & & 3.73 & 5.06 & 4.40 & 0.440 & & & \begin{tabular}{l|l|}
830 & 0.712
\end{tabular} \\
\hline $\mathrm{Sh}_{1}$ & 2.34 & 3.68 & & 2.73 & 4.22 & 3.48 & 0.251 & & & \begin{tabular}{l|l|}
15 & 0.531
\end{tabular} \\
\hline $\mathrm{Sh}_{2}$ & 44 & 4.52 & 8 & 3.46 & 4.94 & 4.20 & 0.337 & & 93 & \begin{tabular}{l|l|}
764 & 0.637 \\
\end{tabular} \\
\hline$\overline{\mathrm{N}_{1} \mathrm{P}_{1}}$ & 4.58 & 6.03 & & 4.68 & 7.48 & 6.08 & 0.761 & & & 0.921 \\
\hline & 5.06 & & & 5.72 & 8.06 & 6.89 & 90 & & & $\begin{array}{ll}70 & 1\end{array}$ \\
\hline & 4.52 & 5.62 & 5.0 & 4.57 & 5.71 & 5.14 & 0.676 & 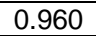 & & \begin{tabular}{l|l|}
38 & 0.912 \\
\end{tabular} \\
\hline$\frac{\overrightarrow{V_{1}}}{1}$ & 4.69 & 6.18 & 4 & 5.35 & 6.96 & 6.16 & 0.761 & 38 & 0 & \begin{tabular}{|l|l|}
50 & 1.011
\end{tabular} \\
\hline $\mathrm{N}_{2} \mathrm{P}_{2}$ & 5.67 & 7.49 & 8 & 7.96 & 10.09 & 9.03 & 0.894 & 2 & 183 & \begin{tabular}{|l|l|}
1.642 & 1.432
\end{tabular} \\
\hline $\mathrm{N}_{2} \mathrm{P}_{2} \mathrm{~K}_{2}+\mathrm{Ch}_{2}$ & 6.67 & 8.11 & 7.39 & 9.06 & 11.15 & 10.11 & 0.998 & 1.413 & 206 & \begin{tabular}{|l|l|}
1.842 & 1.660
\end{tabular} \\
\hline $\mathrm{N}_{2} \mathrm{P}_{2} \mathrm{~K}_{2}+\mathrm{Sh}_{1}$ & 6.25 & 7.44 & 6.85 & 7.46 & 9.33 & 8.40 & 0.922 & 1.277 & 1.100 & \begin{tabular}{|l|l|l|}
1.093 & 1.542 & 1.318 \\
\end{tabular} \\
\hline $\mathrm{N}_{2} \mathrm{P}_{2} \mathrm{~K}_{2}$ & 6.31 & 6.80 & 6.56 & 8.08 & 10.69 & 9.39 & 0.941 & \begin{tabular}{|l|}
1.351 \\
\end{tabular} & 1.146 & \begin{tabular}{|l|l|}
1.679 & 1.459 \\
\end{tabular} \\
\hline Mean & 4.38 & 5.75 & & 5.31 & 7.17 & & 0.662 & \begin{tabular}{|l|}
0.989 \\
\end{tabular} & & 144 \\
\hline L.S.D. & & $\begin{array}{l}32 \mathrm{~B} \\
\mathrm{AB}: \mathrm{N} \text {. }\end{array}$ & & $\begin{array}{l}\text { A:0.80 } \\
\text { AB:N. }\end{array}$ & $\mathrm{B}: 0$ & & A. & 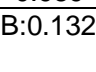 & & $\begin{array}{c}\text { A:0.149 B:0.151 } \\
\text { AB:N.S }\end{array}$ \\
\hline
\end{tabular}

Table (7): Effect of chemical and organic fertilization treatments on the two lines of roselle cultivar Sabahia 17 plants during 2004 and 2005 seasons.

\begin{tabular}{|c|c|c|c|c|c|c|}
\hline \multirow{4}{*}{$\begin{array}{l}\text { Chemical and organic } \\
\text { fertilizer treatments } \\
\text { (B) }\end{array}$} & \multicolumn{3}{|c|}{ First season } & \multicolumn{3}{|c|}{ Second season } \\
\hline & \multicolumn{6}{|c|}{ Lines (A) } \\
\hline & Light & Dark & Mean & Light & Dark & Mean \\
\hline & \multicolumn{6}{|c|}{ K uptake g/ plant } \\
\hline $\mathrm{N}_{0} \mathrm{P}_{0} \mathrm{~K}_{0}$ & 1.18 & 2.08 & 1.63 & 1.72 & 2.38 & 2.05 \\
\hline $\mathrm{N}_{1} \mathrm{P}_{1} \mathrm{~K}_{1}$ & 2.65 & 3.67 & 3.16 & 3.04 & 4.26 & 3.65 \\
\hline $\mathrm{N}_{2} \mathrm{P}_{2} \mathrm{~K}_{2}$ & 3.39 & 4.38 & 3.89 & 3.69 & 5.46 & 4.58 \\
\hline $\mathrm{Ch}_{1}$ & 1.58 & 2.10 & 1.84 & 2.20 & 2.85 & 2.53 \\
\hline $\mathrm{Ch}_{2}$ & 1.90 & 2.69 & 2.30 & 2.67 & 2.88 & 2.78 \\
\hline $\mathrm{Sh}_{1}$ & 1.36 & 2.34 & 1.85 & 1.79 & 2.63 & 2.21 \\
\hline $\mathrm{Sh}_{2}$ & 1.41 & 2.44 & 1.93 & 2.19 & 2.89 & 2.54 \\
\hline $\mathrm{N}_{1} \mathrm{P}_{1} \mathrm{~K}_{1}+\mathrm{Ch}_{1}$ & 2.94 & 3.57 & 3.26 & 3.27 & 3.95 & 3.61 \\
\hline $\mathrm{N}_{1} \mathrm{P}_{1} \mathrm{~K}_{1}+\mathrm{Ch}_{2}$ & 3.38 & 4.26 & 3.82 & 3.60 & 5.03 & 4.32 \\
\hline $\mathrm{N}_{1} \mathrm{P}_{1} \mathrm{~K}_{1}+\mathrm{Sh}_{1}$ & 2.76 & 3.50 & 3.13 & 3.52 & 3.95 & 3.74 \\
\hline $\mathrm{N}_{1} \mathrm{P}_{1} \mathrm{~K}_{1}+\mathrm{Sh}_{2}$ & 2.90 & 3.76 & 3.33 & 3.67 & 4.59 & 4.13 \\
\hline $\mathrm{N}_{2} \mathrm{P}_{2} \mathrm{~K}_{2}+\mathrm{Ch}_{1}$ & 3.83 & 4.29 & 4.06 & 4.38 & 6.01 & 5.20 \\
\hline $\mathrm{N}_{2} \mathrm{P}_{2} \mathrm{~K}_{2}+\mathrm{Ch}_{2}$ & 4.32 & 5.15 & 4.74 & 5.72 & 6.37 & 6.05 \\
\hline $\mathrm{N}_{2} \mathrm{P}_{2} \mathrm{~K}_{2}+\mathrm{Sh}_{1}$ & 3.77 & 4.84 & 4.31 & 4.43 & 5.15 & 4.79 \\
\hline $\mathrm{N}_{2} \mathrm{P}_{2} \mathrm{~K}_{2}+\mathrm{Sh}_{2}$ & 3.96 & 4.58 & 4.27 & 5.17 & 6.32 & 5.75 \\
\hline Mean & 2.76 & 3.58 & & 3.40 & 4.31 & \\
\hline L.S.D. for $5 \%$ & $\mathrm{~A}: 0.26$ & $3: 0.48$ & . & $A: 0$ & $3: 0.54$ & N.S. \\
\hline
\end{tabular}


Ali, A. F.

Concerning $\mathrm{K}$ uptake, it is noticed that fertilizing the plants with $\mathrm{N}_{2} \mathrm{P}_{2} \mathrm{~K}_{2}+\mathrm{Ch}_{2}, \mathrm{~N}_{2} \mathrm{P}_{2} \mathrm{~K}_{2}+\mathrm{Sh}_{1}$ and $\mathrm{N}_{2} \mathrm{P}_{2} \mathrm{~K}_{2}+\mathrm{Sh}_{2}$ were the most effective treatments which produced the highest values $(4.74,4.31$ and $4.27 \mathrm{~g} /$ plant), respectively compared to control (1.63 g/ plant) in the first season and $\mathrm{N}_{2} \mathrm{P}_{2} \mathrm{~K}_{2}+\mathrm{Ch}_{2}$ followed by $\mathrm{N}_{2} \mathrm{P}_{2} \mathrm{~K}_{2}+\mathrm{Sh}_{2}$ gave the best results $(6.05$ and 5.75 $\mathrm{g} /$ plant) in comparison with the check treatment (2.05 g/ plant) in the second season, as clearly shown in Tables (6 and 7 ). These findings concerning $\mathrm{P}$ and $\mathrm{K}$ uptakes are similar to those obtained by Abd El- Malik (1996) on roselle. The promoting effect of NPK fertilization on N, P and K uptakes was emphasized by Hassanein (1991) on roselle and Ali (1993) on Nigella sativa. The efficiency of organic manures in improving $\mathrm{N}, \mathrm{P}$ and $\mathrm{K}$ uptake was observed on anise plants by Hammam (1996) and on sweet basil and thyme by Jacoub (1999). Addition of NPK fertilizers at the recommended doses + FYM gave the highest values of $\mathrm{N}, \mathrm{P}$ and $\mathrm{K}$ in coriander (Mallanagouda et al, 1995).

The interaction between the two studied factors on $\mathrm{N}, \mathrm{P}$ and $\mathrm{K}$ uptakes had no significant effect for the two seasons.

The obtained results could be discussed as follows: The dark line Sabahia 17 cultivar of roselle plants superior to light one in all characters, except acidity \% and that may be due to the difference in the genetic composition potentiality between the two lines. The promoting effect of NPK fertilization on growth, yield and some chemical constituents of the two lines Sabahia 17 cultivar of roselle plants might be attributed to the role of these elements in plant where nitrogen element is one of the basic plant nutrients, it plays a vital role in the metabolism of living organisms. It is built into the body of all simple and conjugated proteins that are major constituents of plant cell cytoplasm and forms part of nucleic acids (RNA and DNA). Phosphorus compounds are an necessity for all living organisms. Not a single living cell can survive without phosphoric acid. Nucleo- proteins constituting the essential substances of cell nuclei contain phosphoric acid. Potassium is accumulating in chloroplasts and mitochondria stabilizers their structure and promotes energy - rich ATP formation in photosynthesis and oxidative phosphorylation. It enhances the cold endurance and winter hardiness of crops (Yagodin, 1982).

The beneficial effect of organic manure on growth, yield and some chemical constituents of the two lines of Sabahia 17 cultivar of roselle may be due to the important role of organic manure, where Waksman (1952) showed that there was a direct correlation between organic manure application and soil fertility. Addition of organic materials increased the organic matter, total nitrogen and hummus in soil ( Abd El- Malek et al, 1968 and Shady, 1970). Moreover, Franz (1973) declared that increasing organic matter content of the soils led to an increase dehydrogenase activity. Schachtschabel (1979) indicated that organic manure holds moisture, maintains sufficient pore spaces to permit good air circulation and excessive water drainage. Bohn et al., (1985) indicated that organic matter could be a main source of $\mathrm{N}, 50-60$ $\%$ of $\mathrm{P}, 80 \%$ of $\mathrm{S}$ and a high content of $\mathrm{B}$ and Mo. Patiram (1994) reported that organic matter content, $\mathrm{pH}, \mathrm{CEC}$, potential $\mathrm{K}$ buffering capacity and exchangeable $\mathrm{K}, \mathrm{Ca}$ and $\mathrm{Mg}$ were increased due to the use of goat manure. 
Generally, it could be deduced that adding organic fertilizers combined with NPK fertilization led to improve the growth, yield and chemical constituents. Using of chicken manure fertilizer achieved better results in comparison to sheep manure fertilizer. In most cases, $50 \%$ of the NPK recommended doses + the high rate of chicken manure gave values near from $100 \%$ of the NPK recommended doses. Furthermore, it is worthy to mention that in some cases, supplying the plants with $\mathrm{N}_{2} \mathrm{P}_{2} \mathrm{~K}_{2}+\mathrm{Ch}_{2}$ led to no significant increase especially in sepals yield production compared to the application of $\mathrm{N}_{1} \mathrm{P}_{1} \mathrm{~K}_{1}$ plus $\mathrm{Ch}_{2}$. Cultivating of dark line plants gave more values in terms of growth, yield and chemical constituents than those of light line cultivar plants, except acidity \%. Therefore, it could be recommended to cultivate dark line or light one plants and using $\mathrm{N}_{1} \mathrm{P}_{1} \mathrm{~K}_{1}+\mathrm{Ch}_{2}$ to obtain high production, minimizing chemical fertilizers, improving of soil fertility and minimizing environmental pollution.

\section{REFERENCES}

Abd-El-Malik, M.H. (1996). Response of roselle plants (Hibiscus sabdariffa,L.) to the combined effects of fertilization and growth regulator treatments. M. Sc. Thises, Fac., of Agric., Minia Univ.

Abd El-Malek, Y.; Monib,M.; Makawi, A.A.M. andSaber,M.S.M.(1968). Sewage farming and its effect on biological, chemical and physical soil properties. Bull, Fac. Agric., Cairo. Univ. Vol. xix.No.1.

Ahmed,E.T; El-Sayed A.A. and Abou-Zeid, M.H.(1995). Response of two lines of Hibiscus sabdariffa,L. cultivar "Sabahia 17" plants to fertilization treatments . Part1. Effect of NPK fertilization. Minia J.Agric. Res\& Dev., Vol. 17, No.4 (1995).

Ahmed, SH.K. : El-Ghawas, E.O. and Ali, A.F.(1998).Effect of activedry yeast and organic manure on roselle plant. Egypt. J. Agric. Res., 76(3), 1998.

Akhtar, J.(1998). Use of fertilizer to increase the yield of paan (Piper betle L.)Hamdard- Medicus, 41 (2) : 103-106. (CAB Abst 1998)

Ali, A.F.( 1993). Response of Nigella sativa L. plants to somefertilization and growth regulator treatments. Ph.D. Dess., Fac. of Agric., El-Minia Univ.

Ali, M.Y.M.(2002). Physiological studies on Foeniculum rulgare Mill, plant under Sinai conditions, M. Sc. Thesis, Fac. Agric., Cairo Univ.

Al-Wandawi,H.;Al-Shaikhly,K.andAbdel-Rahman, M. (1984).Roselleseeds a new protein source. J. Agric. and Food Chemistry, 32 (3) 510-512.

A.O.A.C.(1970). Official Methods of "Analysis of The Association ofOfficial Agricultural Chemists" $11^{\text {th }}$ ed. Washington, D.C.(22. 058).

Badr, A.M. ( 1976). Deficiency of some major elements on the yield and some qualities of roselle plant. M. Sc. Thesis, Fac. of Agric., Ain Shams Univ.

Bhat, V.R. and Sulikeri, G.S. (1992). Effect of nitrogen, phosphorus and potassium on seed yield and yield attributes of coriander

(Coriandrum sativum) . Karnataka J. Agric.,Sci. 5 ( 1): 25-30 (c.f. Hort Abst., $64,1366)$. 
Ali, A. F.

Bohn, H.L.: Mcneal, B.L. and O.Connor, G.A.(1985).Soil chemistry.2 ${ }^{\text {nd }}$ ed. Awiley - Interscience Publication. John Wiley \&Sons New York Toronto, Singapore.

Busson,F.:Garnier,P.and Daniel, P.(1957).Amino acids content of the calyces of Hibiscus sabdariffa. J. Agric. Trop. Et Boton Appl. 4: 265-266. (c.f.Chem. Abst. 54, 19989d)

Caceres, A.;Giron, L.M.and Martinez,A.M.(1987).Diuretic activity of plants used for the treatments of ailments in Guatemala J. of Ethno pharmacology, 19 (3): 133-245.

Damme, P.V. and Viaene, N. (1987). Optimal proportions between, S and P between $\mathrm{K}, \mathrm{Ca}$ and $\mathrm{Mg}$ in the fertilization of roselle

(Hibiscus sabdariffa L.).Total Agriculture (1987) 64(4): 279-282. Fac. of Agric., Sci., State Univ. of Ghent, 9000 Ghent, Belgium (c.f. Hort Abst., $59,1989,1191)$.

Du, C.T. and Francis, F.J.(1973). Anthocyanin of roselle J. Food. Sci., 38:810-812.

El-Shafi S.A. (1979).Effect of different fertilization rates on the growth and yield of roselle in Egypt. Ind. J. Agric., Sci., 49(2): 118-119 (Field Crop Abst, 33,1979, 2336).

El-Syed, A.A.;Ahmed, E.T.;and Abou-Zeid, M.H.(1995).Response of two lines of Hibiscus sabdariffa. L cultivar "Sabahia 17" plants to fertilization treatments. Part 11. Effect of some nitrogen sources.

Accepted for publication in Minia J. Agric. Res \& Dev. Eweida,M.A.(1974).Influence of planting dates, stem diameter and retting, methods on chemical in roselle fibers. Al-zhar Agric., Res. Bull., No.3, Fac., of Agric., Al - Azhar Univ.

Franz, G.(1973). Comparative investigations on the enzyme activity ofsome soil in Nordrhein - Westfalen and Rheinlandpflaz. Pedobiologia 13 (6); 423. (c.f. Soil and Fert. 37,8).

Fuleki, T. and Francis, F.J.(1968). Quantitative methods for anthocyanin. J. Food Sci. 23,72.

Griebel,C.(1939). Hibiscus flowers, a drug used in the preparation of food character ( Hibiscus acid).Ziuntersuch. Lebensn, 77:561-71.(c.f. Chem. Abst. $33: 7491,1939)$

Guerin, J.C. and Reveillere, H.P.(1984). Antifungal activity plant extracts used in therapy. 1 . Study of 41 plant extracts 9 fungal species. Annales Pharmaceutigues Francaises 42 (6) : 553- 559.

Hammam, K.A.M.(1996).Effect of nitrogenous fertilization and irrigation on growth, yield and active constituents of anise plants. M.Sc.Thesis Fac. Agric. Cairo Univ.

Hassanein, M.A.(1991). Physiological studies on roselle (Hibiscus sabdariffa L.) plants. Ph. D. Dess. Fac. of Agric., Cairo Univ.

Jacoub,R.W.(1999).Effect of some organic and non- organic fertilizers on growth, oil yield and chemical composition of Ocimum

basilicum L. and Thymus vulgaris P. plants. Ph. D. Thesis, Fac.Agric., Cairo Univ. 
Kirby. R. H.(1963). Vegetable fibers ed by praf. Nicholas pulluniun pp 129, 31 in Terscience Publishers, INC. New York (c.f. Haridi S.M.M.) M.Sc. Thesis, Ain Shams Univ. 1980.

Little, I.M. and Hills, F. J.(1978).Agricultural Experimentation, Design and Analysis. John Wiley \& Sons, Inc. New York, U.S.A.Mallanagouda, B.; Sulkeri, G.S.; Hulamani,N.C.; Murthy,B.G. and

Madalgeri, B.B.(1995). Effect of NPK and FYM on growth parameters of onion, garlic and coriander. Current Res., Univ., of Agric., Sci., Bangalore. 24: 11, 212-213.

Mohsen, M.M.A.(2002). Sweet basil and oil production as affected by chemical and organic fertilization. M.Sc. Thesis, Fac. Agric., Cairo Univ.

Osman, Y.A.H.(2000).Possibility of production of coriander ( Coriandrum sativum L.) under Sinai conditions. Ph. D. Thesis, Fac.Cairo Univ.

Page, A.L. ;Milier, R. H. and Kenney, D. R.(1982).Methods of SoilAnalysis. part 11. American Society of Agronomy. Madison, Wisconsm, U.S.A.

Patiram.(1994). Effect of organic manure and nitrogen application on potassium quality intensity relationship in an acid Inceptisol. J. of the Indian Society of Soil Science, 42: 1.136- 139.

Schachtschabel, S.(1979).Lehrbuch der Bodenkunde. Printed in Germany ( F.R.G.).Fedinand Enke, Stuttgart.

Shady, M.A.M.(1970). Microbiological studies on kharga oasis soils. M.Sc. Thesis, Fac. Agric. Cairo Univ.

Sidky, Mahassen M.A.;Harridi, I.M.A. and Mousa, I.A.I.(1997). Using chemical and organic fertilizers for nutrition of roselle (Hibiscus sabdariffa L.) plants irrigated at different intervals.

Egypt.J.App. Sci., 12 (9): 123-135. Waksman,S.A. (1952). Soil Microbiology. John Wiley \& Sons, Inc., New York.

Yagodin,B.A.(ed.)(1982). Agricultural Chemistry, Part 1. Mir Publichers, Moscow, USSR. 
Ali, A. F.

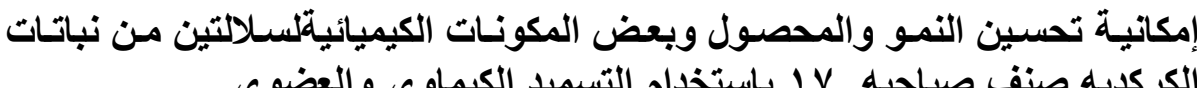

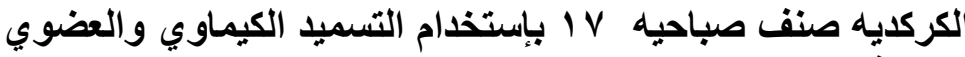

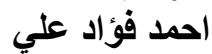
قسم البساتين كليه الزراعة جامعة الأزهر اسيوط.

أجريت هذه الدراسة خلال موسمين متتاليين ع ـ. بو ه . . ب لتحديد دور التسميد المعدني

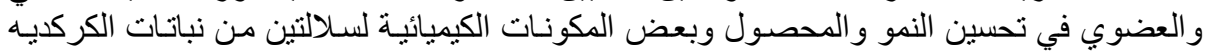

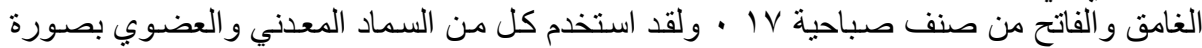

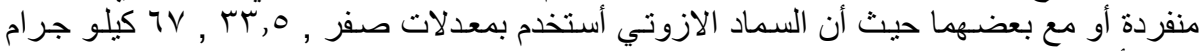

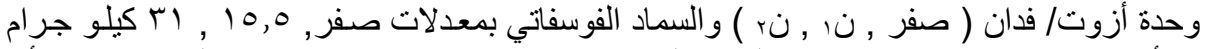

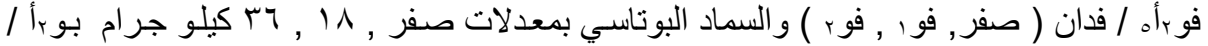

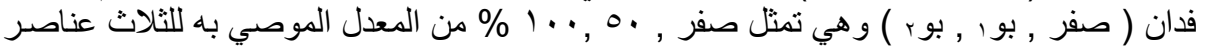

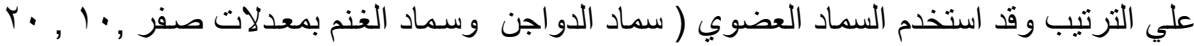

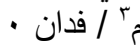

$$
\text { أوضحت النتائج المتحصل عليها الاتى:- }
$$

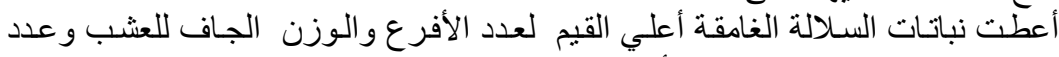

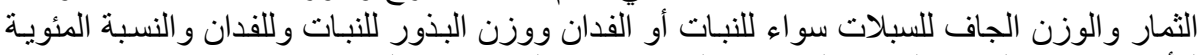

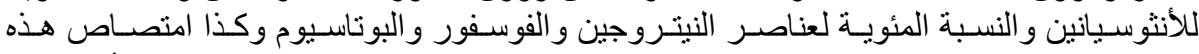

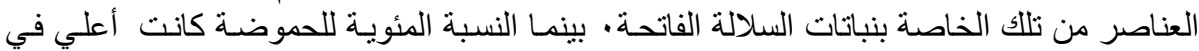

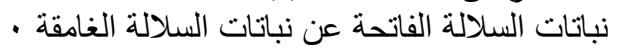

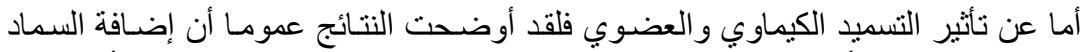

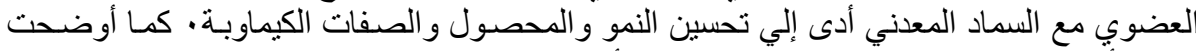

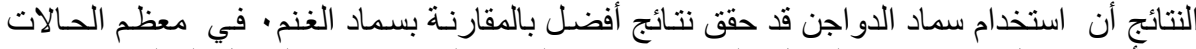

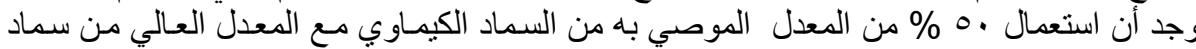

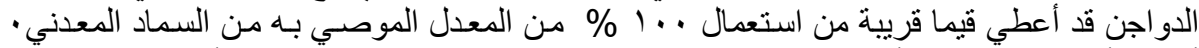

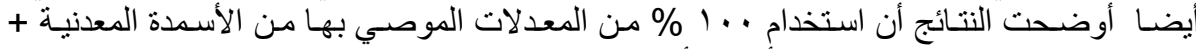

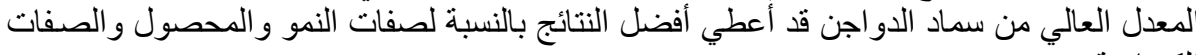

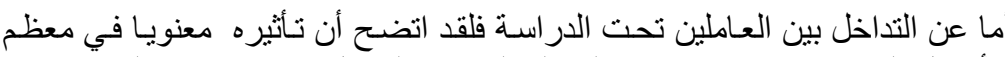

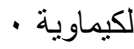

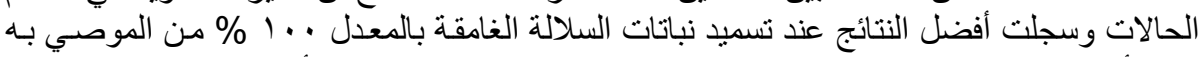

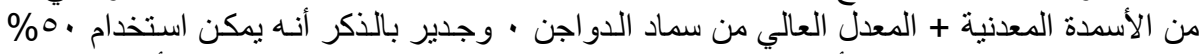

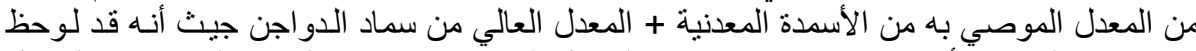

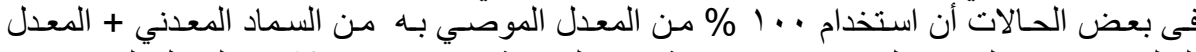

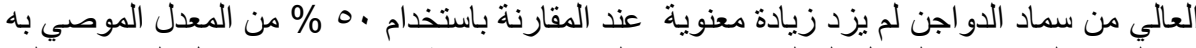

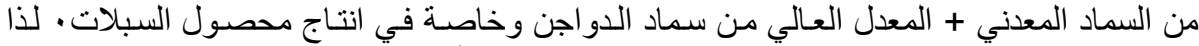

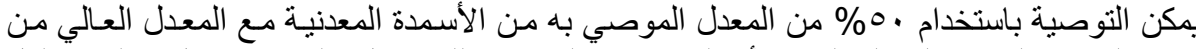

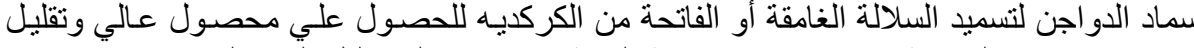
استخدام الاسمده المعدنية وكذا تحسين خصوبة التزبة با لإضافه إلي تقليل تلوث البئه البئه . 